\title{
Child Adoption in Western Europe, 1900-2015
}

\author{
Cliometrics of the Family. Global Patterns and Their Impact on Diverging \\ Development
}

\section{Summary}

This chapter is a first step towards a comparative history of child adoption law and practices in Western Europe since child adoption became legal in Germany (1900), Sweden (1917), France (1923), England and Wales (1927) and Italy (1942). Relying mainly on long time series from these five countries, I analyze the incidence and the developments of domestic adoptions of both unrelated and related children as well as more recent developments in inter-country adoption. In most Western European countries child adoption incidence increased from the early $20^{\text {th }}$ century to approximately the 1970 s, likely because of rising demand for child adoption. Child adoption incidence has decreased since the 1970s because of a fall in adoptable children from both domestic and foreign backgrounds. In addition, the people of Sweden and England and Wales have long adopted children much more frequently than those of Germany, let alone France and Italy. The history of child adoption in Western Europe thus reflects major demographic trends since 1900 as well as a North-South gradient in child adoption incidence.

\section{Keywords}

Adoption; Fostering; Infecundity; Abandonment; Illegitimacy; Step-family; Family Law; Western Europe; $20^{\text {th }}$ century; $21^{\text {st }}$ century.

\footnotetext{
${ }^{1}$ For their precious help I wish to thank Christina Benninghaus, Francesca Caroccia, E. Wayne Carp, Nina Dethloff, Vincent Gourdon, Joachim Haas, Juliette Halifax, Juho Härkönen, Tobias Hübinette, Jenny Keating, Silvia Leek, Philippa Levine, Jörg Lewe, Cecilia Lindgren, Li Ma, Agnès Martial, Christoph Neukirchen, David Reher, Paola Ronfani, Peter Selman, Julie Selwyn, June Thoburn and the anonymous reviewers.
} 


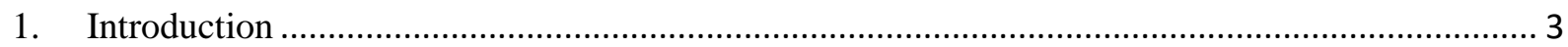

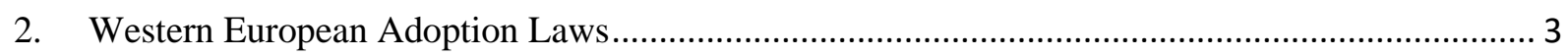

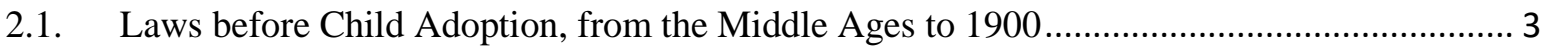

2.2. Laws Allowing Child Adoption since 1900 .................................................................... 4

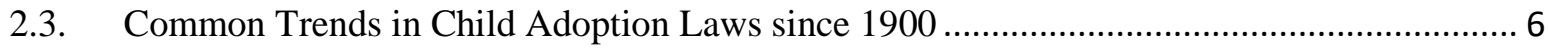

3. Statistical Sources on Child Adoptions in Germany, Sweden, France, England and Wales, and

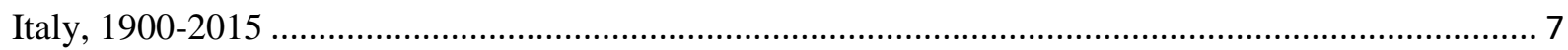

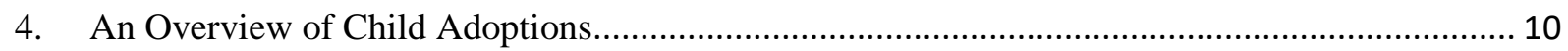

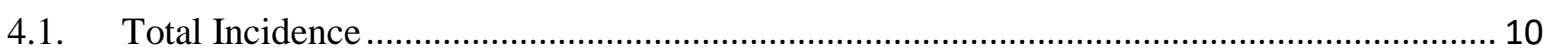

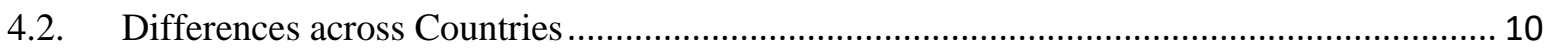

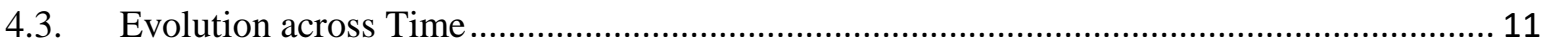

5. Domestic Adoptions of Unrelated Children .............................................................................. 11

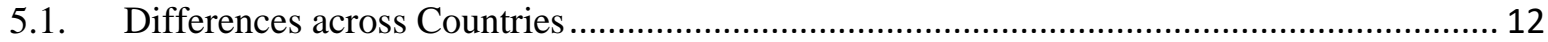

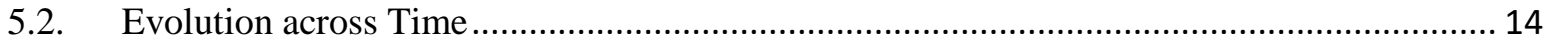

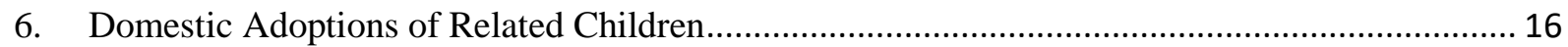

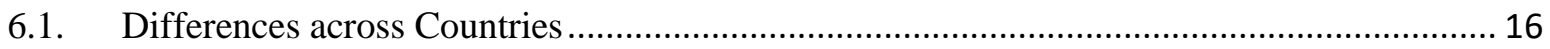

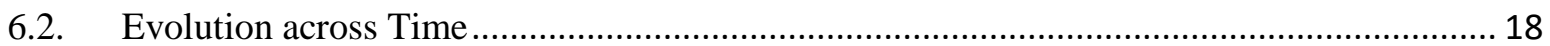

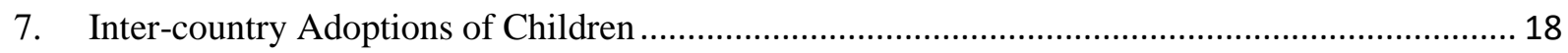

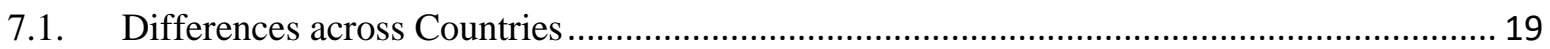

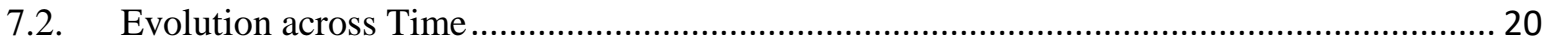

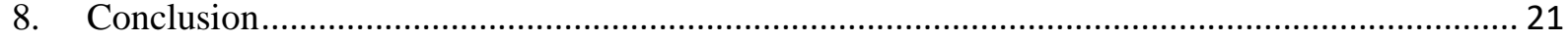

Appendix

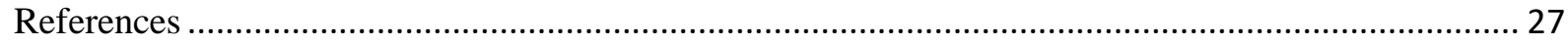




\section{Introduction}

Child adoption reveals to what extent a population is willing to consider that a child may belong to and inherit from a family other than its birth family. As such, it is a significant aspect of a population's socio-demographic behavior (United Nations 2009; Leinaweaver 2015). This is why several social scientists have studied the history of adoption in the United States (Carp 1998; Herman 2008; Conn 2013), including its quantitative dimension (Moriguchi 2012). However, little is known about the history of child adoption in countries other than the United States, including European countries (Corbier 1999; Rossi et al. 2014). There are few or no mentions of adoption in the main reference works and literature reviews on European childhood history (Becchi and Julia 1996; Heywood 2001; Lett et al. 2015; Stearns 2015), family history (Ariès and Duby 1990-1998; Burguière et al. 1996; Kertzer \& Barbagli 2003; Therborn 2004), social history (Stearns 2001), population history (Bardet and Dupaquier 1997-1999), demography (Caselli et al. 2005), family economics (Bergstrom 1997; Schultz 2015) and cliometrics (Diebolt and Haupert 2016), ancient and medieval childhood history being an exception (Dasen et al. 2001). Furthermore, what is known about adoption history in Europe lacks a comparative dimension.

How do adoption laws and practices compare among Western European countries? When did Western Europeans adopt the most children? Did some countries adopt more children than others? The main objective of this chapter is to establish stylized facts on child adoption in Western Europe and to compare child adoption incidence since the early $20^{\text {th }}$ century, when Germany, Sweden, France, England and Wales, and Italy were among the first Western European countries to introduce child adoption in their laws. This chapter surveys Western European adoption laws and uses publicly available and comparable data to analyze the evolution of the incidence of child adoption in Western Europe since 1900. This includes domestic adoptions of unrelated and related children as well as inter-country adoptions. I also speculate on possible explanations of these patterns and trends.

\section{Western European Adoption Laws}

Adoption is a legal institution that creates a parent-child relationship between a couple or an individual (the adopter) and another, younger person (the adoptee) so that the adoptee inherits from the adopter's surname and property and is subjected to its parental authority. The adopted child may be an orphan, a child who was (legally or illegally) abandoned, a child who was removed from its abusive parents, a foreign child or kin such as a step-child who is adopted following one of its parents' widowhood or divorce and remarriage. As adoption creates a parent-child relationship, it differs not only from the Islamic legal institution of kafala, which creates a legal bond but not a parent-child bond, but also from other "fictive" kinship relationships such as spiritual kinship (Fine 1999; Alfani and Gourdon 2012). As a legal institution, adoption also differs from fosterage, an informal arrangement which is found in most stateless societies of the past and also in many present-day societies in the world, including Western Europe (Goody 1969; Lallemand 1993; Volk 2011).

\subsection{Laws before Child Adoption, from the Middle Ages to 1900}

Although adoption was well developed in ancient Roman law, it largely disappeared from most Western European legal systems from the early Middle Ages to the late $18^{\text {th }}$ century (Lett 1998; Fauve-Chamoux 1998; Burguière 1999). During this period there were almost no formal adoptions. Given that no process entitled a single or a married couple to create a legal parent-child relationship, foster parents ran the risk that the child's birth parents or other relatives would take the child back. The Western European context was one of deep suspicions against including strangers into the family, especially the illegitimate children of fallen women whose "bad blood" could spoil the lineage's heritage (Laslett et al. 1980; 
Fauve-Chamoux and Brunet 2014). From early times however, the Catholic Church rejected not only the adoption of illegitimate children but also the adoption of legitimate children as well as adults, likely because this prevented childless people from having an heir and enabled the Church to collect their inheritances (Goody 1983). When the first Western European civil codes reintroduced adoption like in France (1804), Saxony (1865) and Italy (1865), they allowed adult adoption only (Table 1; Mignot 2015a; Mignot 2015b).

Before child adoption was allowed, Western European orphans and abandoned children were usually cared for by institutions such as orphanages and foundling hospitals, which boarded out some of the children to remunerated foster parents. Once these children reached the age of twelve or so, most were placed as servants or apprentices in households in need of additional labor. From the mid- $19^{\text {th }}$ century, European foundling hospitals and baby hatches closed, single mothers' rights to sue the father (for child legitimation or alimony) were strengthened, and child abandonment became less frequent (Hunecke 1991; Bardet and Faron 1996). From the late $19^{\text {th }}$ century, Western European lawmakers also started protecting children against child work and abusive families. By contrast, until then lawmakers had mostly protected legitimate families against the claims of illegitimate children. Laws allowing child adoption since 1900 should thus be seen in the context of an emerging public concern for the welfare of children, including illegitimate children who were deprived of certain inheritance rights.

\subsection{Laws Allowing Child Adoption since 1900}

The first Western country which introduced child adoption was the United States, with the Massachusetts Act to Provide for the Adoption of Children (1851) and successive acts in other states until the 1870s. Similar laws were then enacted in New Zealand (1881), Western Australia (1896) and British Columbia (1920). By contrast, Western European legal systems did not acknowledge child adoption until the early $20^{\text {th }}$ century, when they acknowledged child adoption under the form of "simple" and/or "full" adoption (Tables 1 and 2). Full (or "plenary," "special" or "strong") adoption eliminates the child's previous legal relationship with birth parents: it substitutes a parent-child relationship with a new, exclusive one. As a consequence, the adoptee may not simultaneously have more than two parents. By contrast, simple (or "ordinary" or "weak") adoption creates a parent-child relationship without eliminating the child's previous legal relationship with birth parents. Simple adoption only adds a parent-child relationship and the adoptee might have and inherit from up to four parents. Only the simple adopters, not the birth parents usually have parental authority, though. In contrast with England and Wales, a common-law country which never acknowledged simple adoption (Lavallée 2008) and acknowledged full child adoption directly in 1927, codified civil-law countries acknowledged simple child adoption first (Table 1). 
Table 1. Year when Adoption was Allowed in Western European Countries

\begin{tabular}{|c|c|c|c|}
\hline & Adult adoption & Simple child adoption & Full child adoption \\
\hline (West) Germany & 1900 & 1900 & 1977 \\
\hline Sweden & 1917 & 1917 & 1959 \\
\hline France & 1804 & 1923 & 1939 \\
\hline England-Wales & \multicolumn{2}{|c|}{ Never acknowledged } & 1927 \\
\hline Italy & 1865 & 1942 & 1967 \\
\hline
\end{tabular}

Sources: Rieg 1985; United Nations 2009.

Note: simple child adoption has been allowed in Germany from 1900, in Sweden from 1917, etc. Adult adoption and simple child adoption have never been acknowledged in England-Wales.

Field: in this chapter, Germany is understood as the whole of Germany until 1949, West Germany in 1950-1990 and the whole country again since 1991. Because of the lack of British data this chapter bears on England and Wales only, not Scotland or Northern Ireland.

Table 2. Sources on Western European Child Adoption Laws

\begin{tabular}{|c|c|c|c|}
\hline & Early $20^{\text {th }}$ century & Late $20^{\text {th }}$ century & Early $21^{\text {st }}$ century \\
\hline (West) Germany & $\begin{array}{l}\text { Florsch 1985; Neukirchen } \\
\text { 2005; Mouton } 2005\end{array}$ & $\begin{array}{l}\text { Florsch 1985; Neukirchen } \\
\text { 2005; Benicke } 2003\end{array}$ & $\begin{array}{c}\text { Neukirchen 2005; } \\
\text { O’Halloran 2015, Chap. } \\
\text { 14; Center for Adoption } \\
\text { Policy 2016a } \\
\end{array}$ \\
\hline Sweden & \multicolumn{2}{|c|}{ Lindgren 2002; Lindgren 2006} & $\begin{array}{l}\text { O'Halloran 2015, Chap. } \\
\text { 12; Center for Adoption } \\
\text { Policy 2016b }\end{array}$ \\
\hline France & Gutton 1993 & Neirinck 2000 & $\begin{array}{l}\text { O'Halloran 2015, Chap. } \\
13\end{array}$ \\
\hline England-Wales & Keating 2009 & $\begin{array}{l}\text { Flauss-Diem 1985; } \\
\text { O'Donovan } 2003\end{array}$ & $\begin{array}{l}\text { O'Halloran 2015, Chap. } \\
\text { 6; Center for Adoption } \\
\text { Policy 2016c }\end{array}$ \\
\hline Italy & \multicolumn{2}{|c|}{ Brand 1985} & $\begin{array}{c}\text { Center for Adoption } \\
\text { Policy 2016d }\end{array}$ \\
\hline
\end{tabular}

The first Western European country to introduce child adoption was Germany. Child adoption was already allowed in some pre-1900 German states, e.g. in Prussia where, since the 1794 civil code, a few step-children were adopted (Neukirchen 2005). The 1900 German civil code replaced the German states' laws with a harmonized civil legislation and it allowed the adoption of both adults and children. Most adoptions were adult adoptions until the 1910s but since the 1920s most adoptions involved children (Florsch 1985; Benninghaus 2013). From 1900, married couples and singles over 50 years old and without legitimate children could adopt as long as they were at least 18 years older than the adoptee. Adoptees kept their legal links with their birth family (they still inherited from each other) and they benefited from the adopter's surname and inheritance. Adoptees formed a legal link with the adopter only, which means that they could not inherit from the adopter's relatives. Later, West Germany allowed adoptions by adopters who had legitimate children (1961) and by adopters who were as young as 35 (1961) or even 25 years (1973). Germany was also the last of the five Western European countries studied here to allow full child adoption, through a 1976 law which came into force in 1977.

When Sweden introduced adult and child adoption (1917), it allowed adoption by singles and married couples over 25 years old without legitimate children (see Le Bouteillec 2013 on the law's family policy context). The legal effects of adoption were similar to those in Germany. Later, Sweden also allowed adoptions by parents of legitimate children (1944) and by same-sex couples (2003). France introduced child adoption through a 1923 law which 
was broadly similar to those in Germany and Sweden. Later, the French lawmaker also allowed adoptions by parents of legitimate children (1976) and by adopters as young as 30 years old (1966) and 28 years old (1996), as well as by same-sex couples (2013).

England and Wales introduced full child adoption through the Adoption of Children Act 1926, which came into force in 1927 (Northern Ireland followed in 1929 and Scotland in 1930). Married couples and singles over 25 years old could adopt a child even if they already had a legitimate or illegitimate child, except single males who usually could not adopt a girl. Adoptees kept some of their inheritance links with their birth family but few adoptees inherited from their birth parents. Moreover, until the Adoption of Children Act 1949, adoptees had to be named in the adopter's will to inherit. England and Wales later allowed adoption by same-sex couples (2002). Finally Italy introduced child adoption in its 1942 civil code. Singles and married couples over 50 years old and without legitimate children could adopt a child, but only an Aryan child (this provision was eliminated by the royal decree of 20 January 1944). Italy then allowed adoptions by parents of legitimate children and by adopters as young as 18 years old (1967).

Why did Western European lawmakers allow child adoption despite the deep-seated suspicion against it? Let's analyze child adoption laws in reverse chronological order. The Italian government allowed child adoption (1942) to care for Second-World-War orphans. Similarly, the French allowed child adoption (1923) to secure the legal status of fostered FirstWorld-War orphans, many of whom were the legitimate children of national heroes (Jablonka 2006). Similarly, England and Wales allowed child adoption (1926) to secure the legal status of the growing numbers of "war babies" born from wartime liaisons who in the early 1920s were fostered by families (Keating 2001; Behlmer 2002; Keating 2009). The English and Welsh adoption law was passed on the initiative of child protection and adoption societies, in order to eliminate "baby farming" and related child abuse (Chassaigne 1992). Another objective was to create a secure legal bond between the child and its parents (Keating 2001), in a time when adopters' fear was that natural parents might reclaim their child, thus making a scandal (Keating 2009, Chap. 3). The war also increased the number of childless persons, including war widows and couples who had lost an only child. Some childless people adopted out of patriotism and other altruistic motives, others to have a child who could later work and care for them, and still others to have a child to raise and love.

However in Sweden, a country whose population was not directly hit by the First World War (Ined 2016), the decision to allow child adoption (1917) was taken "to benefit the child" (Socialstyrelsen 2009, p. 11), - not so much war orphans but rather illegitimate and poor abandoned children (Lindgren 2002; Lindgren 2006). In Germany too child adoption (Minderjährigenadoption) was allowed (1900), among other things, as a child protection measure to care for abandoned, often illegitimate children (Mouton 2005; Benninghaus 2013). The adoption of institutionalized children relieved the state from a financial burden and was supposed to reduce the children's risk of becoming criminals (Walker 2006). More generally, Western Europeans' suspicion against establishing a parent-child relationship with abandoned, illegitimate children may have eroded at the turn of the $19^{\text {th }}$ and $20^{\text {th }}$ centuries. As infant mortality and fertility dropped (Coale and Cotts Watkins 1986; Vallin 2005) and parents intensified their emotional investments in children (Thomson 2015), childless couples may have been more and more willing to adopt young children in order to raise and love them like their own.

\subsection{Common Trends in Child Adoption Laws since 1900}

Western European child adoption laws have followed at least four common trends since 1900. First, child adoptions have been facilitated more. In the early $20^{\text {th }}$ century, only mature individuals and couples could adopt a child, because lawmakers wanted to avoid that young 
couples adopt rather than have children. In addition, only childless individuals and childless couples could adopt because lawmakers wanted to avoid adoption penalizing legitimate children's inheritance. By contrast, in the early $21^{\text {st }}$ century the conditions for adopting are less strict, which is aimed at giving parentless children a higher chance of being adopted and raised in their own family.

Second, more child adoptions have been full rather than simple adoptions. In the early $20^{\text {th }}$ century simple adoption was seen as well suited to increase the number of parents on whom a child may rely without severing the legal bonds with the birth family, which was often considered as too cruel for the birth parents. In the course of the century, however, full adoption came to be seen as in the "best interests" of the child and most able to cater for its need of exclusive attachment. Now most adoptive families are the child's only family. Most adoptees have a legal link not only with their adoptive parents but also with their adoptive parents' parents, siblings and other kin and they can inherit from each other.

Third, adoption has been designed more in children's interest. While in civil-law countries child adoption initially was a private contract, it has become a court decision whereby judges must aim at the child's best interests. Nowadays, a child may be adopted only if its parents consent to the adoption - or if the child is an orphan or is neglected or abused by its parents and the latter are deprived of their legal bonds with it. Adoption candidates are screened to ensure that they have the material and parenting capacities required to adopt and they have a trial period before the adoption may be ordered. One major interruption to this long-term trend was Nazi Germany, however: "While Weimar authorities sought financially and emotionally stable homes that would ensure child welfare, the Nazis dramatically altered the standards for what constituted a 'good parent' by focusing primarily on racial criteria." (Mouton 2005, p. 567; personal communication by Jörg Lewe).

Fourth, child adoption was made more difficult to revoke. In Sweden for instance, the 1917 law acknowledging simple child adoption allowed the adopter to revoke the adoption and return the child to its birth family (Lindgren 2002; Lindgren 2006). A 1944 law, which was voted in the context of the "mental hygiene" and eugenics movement seeking to separate ill from other children, extended adopters' revocation rights to five years, as long as the child suffered from a severe defect which predated the adoption and was unknown to parents at that time. The 1970 law abolished Swedish adoption revocation though, in order to avoid that adoptive parents try to escape their responsibilities or threaten their child with adoption revocation. This was especially important in the context of rising inter-country adoptions; otherwise, some children could have become stateless. While in the early $20^{\text {th }}$ century many, perhaps most child adoptions in Western Europe could be revoked, in the early $21^{\text {st }}$ century most cannot.

In the end, since 1900 Western European child adoption legislations have converged toward a common conception of adoption as a way to give children in need of protection the best possible legal status, i.e. the status initially reserved for legitimate children. In addition, the child's interest has been conceived in a more encompassing way (Lindgren 2002; Lindgren 2006).

\section{Statistical Sources on Child Adoptions in Germany, Sweden, France, England and Wales, and Italy, 1900-2015}

The most easily available and interpretable measure of child adoption incidence is the annual number of child adoptions per 100,000 people. The annual number of child adoptions per 1,000 live births is also found in the literature but this indicator has two drawbacks: (i) it has little relevance in times when few adoptees are newborns; and (ii) high year-to-year variations in birth rate harm this indicator's robustness (Appendix, Figure A). 
Data on child adoption is scarce. In England and Wales and other countries, data protection laws make access to registers problematic and many registers have been lost or destroyed (Keating 2009, p. 9). In this context most statistical data on child adoption are country-level data (Table 3). These aggregate data are usually of administrative origin (judicial or civil state statistics). These are comprehensive data on formalized, registered adoptions. However, the information on the profile of adopters, adoptees and birth parents is usually minimal or nonexistent.

The most common counting unit is the number of adoptees, by year of court order. Concerning inter-country adoption, most available statistics report the annual number of foreign-born children who were authorized to enter the country for adoption, which may slightly differ from the number of inter-country adoptees in the same year. However, such details cannot seriously affect child adoption's order of magnitude or long-term evolution. Although most series start on the year when child adoption was legalized, I have not been able to find Italian data from 1942 to 1954 . And when data are available they may not be easily comparable. While some countries like Germany, Sweden and England and Wales publish data on child adoption but not on adult adoption, other countries like France and Italy publish data on full and simple adoptions and often do not specify whether simple adoptees are children or adults. 
Table 3. Statistical Sources on Western European Countries' Child Adoptions, 1900-2015

\begin{tabular}{|c|c|c|c|}
\hline & Sources on domestic adoptions & Sources on inter-country adoptions & Sources on total mid-year population \\
\hline $\begin{array}{l}\text { (West) } \\
\text { Germany }\end{array}$ & $\begin{array}{c}\text { Glässing } 1957 \text { (1900-1933); Statistisches } \\
\text { Bundesamt } 2015 \text { (1950-2014) }\end{array}$ & Statistisches Bundesamt 2015 (1982-2014) & $\begin{array}{c}\text { Maddison } 2003 \text { (1900-1949 and 1991-1999); } \\
\text { Statistisches Bundesamt } 2015 \text { (1950-1990); } \\
\text { United Nations Population Division 2015a } \\
\text { (2000-2015) }\end{array}$ \\
\hline Sweden & $\begin{array}{l}\text { Hübinette 2001a (1918-2001); Lindgren } 2006 \\
\text { p. 33-35 on Stockholm only (1922-1975) }\end{array}$ & $\begin{array}{c}\text { Hübinette 2001a and Hübinette 2001b (1969- } \\
\text { 2004); Australian inter-country adoption } \\
\text { network } 2016 \text { (2005-2013); Statistiska } \\
\text { centralbyrån 2016 (2000-2014) }\end{array}$ & $\begin{array}{l}\text { Maddison } 2003 \text { (1900-1999); United Nations } \\
\text { Population Division 2015a (2000-2015) }\end{array}$ \\
\hline France & $\begin{array}{c}\text { French Ministry of Justice's statistical } \\
\text { yearbook presented in Mignot 2015a (1923- } \\
\text { 1981); Observatoire national de l'enfance en } \\
\text { danger 2007-2016 (1989-2015); Belmokhtar } \\
\text { 1996 (1992); Belmokhtar 2009 (2007) }\end{array}$ & $\begin{array}{l}\text { Ministère des Affaires étrangères } 2016 \text { (1979- } \\
\text { 2015) }\end{array}$ & $\begin{array}{l}\text { Maddison } 2003 \text { (1900-1999); United Nations } \\
\text { Population Division 2015a (2000-2015) }\end{array}$ \\
\hline $\begin{array}{l}\text { England- } \\
\text { Wales }\end{array}$ & $\begin{array}{l}\text { Office for National Statistics } 2013 \text { (1927- } \\
\text { 2012); Masson et al. } 1983(1950-1956) \\
\text { Selman 2006a (1959-1984) }\end{array}$ & $\begin{array}{l}\text { Selman 2006a and Office for National } \\
\text { Statistics } 2013 \text { (1993-2013) }\end{array}$ & $\begin{array}{l}\text { A Vision of Britain Through Time } 2009 \text { (1900- } \\
\text { 2011); Office for National Statistics } 2015 \\
\text { (2014) }\end{array}$ \\
\hline Italy & $\begin{array}{c}\text { Brand } 1985 \text { (1955-1979); Istat } 2011 \text { (1968- } \\
\text { 2008); Giustizia Minorile } 2003 \text { and Giustizia } \\
\text { Minorile } 2014 \text { (adozioni di casi particolari, } \\
\text { 1993-2008) }\end{array}$ & $\begin{array}{l}\text { Istat } 2011 \text { (1986-2008); Commissionne per le } \\
\text { adozioni internazionali } 2014 \text { (2001-2013) }\end{array}$ & $\begin{array}{l}\text { Maddison } 2003 \text { (1900-1999); United Nations } \\
\text { Population Division 2015a (2000-2015) }\end{array}$ \\
\hline
\end{tabular}

Dates in parentheses refer to the earliest and latest data points available. 


\section{An Overview of Child Adoptions}

\subsection{Total Incidence}

The annual incidence of child adoption in Western Europe has always been lower than 80 adoptions per 100,000 people, i.e. it never reached the level of 1 adoption per 1,000 people (Figure 1). In other words: although our (incomplete) data comprise more than $1,600,000$ child adoptions in the $20^{\text {th }}$ century and 200,000 more from 2000 to 2014, child adoption has remained a relatively infrequent demographic event.

Figure 1. Child adoptions per 100,000 people in Western Europe, 1900-2015

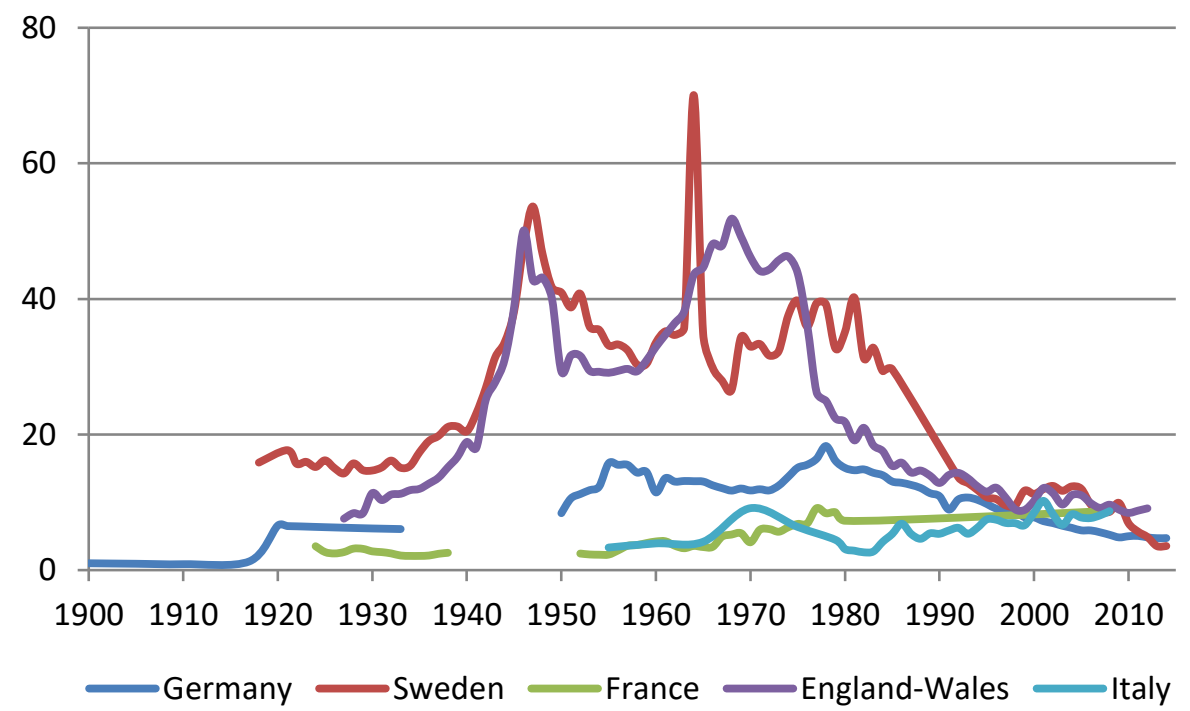

Sources: see Table 3 .

Swedish data are slightly underestimated from 1918 to 1968 (they include domestic adoptions only) and from 2002 to 2014 (they include inter-country adoptions only). French data from 1924 to 1938 are estimated, not observed numbers; French data from 1952 to 1980 are underestimated (they include full child adoptions only, not simple child adoptions). English and Welsh data are slightly underestimated from 1927 to 1992 (they include domestic adoptions only).

\subsection{Differences across Countries}

Until the 1990s child adoption incidence has been higher in Sweden and in England and Wales than in Germany, let alone France or Italy (Figure 1). While there were more than 15 child adoptions per 100,000 people in Sweden and almost as many in England and Wales from the 1920s to the 1990s, this has rarely been the case in Germany, and never in France or in Italy. Child adoption incidence never even reached the level of 10 adoptions per 100,000 people in France and it reached this level only once (in 2001) in Italy. The gap in child adoption incidence was particularly impressive from the mid-1940s to the mid-1970s, when relatively speaking there were at least twice as many child adoptions in Sweden and England and Wales as in Germany, and at least four times as many as in France or Italy. Since the 1990s, differences in child adoptions across Western European countries have been much smaller.

Sweden and England and Wales have few common legal, linguistic or religious points, including traditional family structures (Carmichael et al. 2016), that Germany, France or Italy do not also share (Appendix, Table A). How, then, could one explain this North-South gradient in child adoption incidence, which we will see reflected gaps in domestic adoptions of both unrelated and related children? Let us speculate. In Western Europe from the $16^{\text {th }}$ to 
the $19^{\text {th }}$ centuries, most Northern agricultural households took in adolescents from other families to work as "life-cycle servants." These young people left their home to work and save some capital before marriage. As a consequence, most households were used to having non-kin members among them. By contrast, fewer Southern agricultural households took in servants and those who did, usually did so for a shorter period of time (Reher 1998). Therefore, when child adoption was legally allowed in the $20^{\text {th }}$ century, it might have been seen as relatively normal in Northern Europe while Southerners may have conceived it as a threat to family cohesion. The fact that Northern families have long tended to be more open than Southern families cannot on its own be considered a proper explanation of the observed North-South European gradient in adoption incidence, though, because we still do not understand precisely why Northern European families differed from Southern ones.

\subsection{Evolution across Time}

In most Western European countries, child adoption incidence increased from the interwar period to the 1970s. In Sweden and England and Wales, the two countries which have the best data on child adoptions following the Second World War, the conflict led to a peak in child adoptions. There were more than 50 child adoptions per 100,000 people in England and Wales in 1946 and also in Sweden in 1947, despite the fact that Sweden remained neutral during the war. These adoptees might be war orphans, illegitimate war babies abandoned by their birth mother, legitimate babies abandoned by a war widow or widower, step-children adopted following the post-war divorce peak and a few children adopted from abroad. The unusually high peak in child adoptions in Sweden in 1964 (70 adoptions per 100,000 people) would require a separate explanation.

Since the 1970s child adoption incidence has decreased in most countries, mainly because of a drop in the "supply" of adoptable children. Adoption incidence started declining in England and Wales following the 1968 peak because of a fall in domestic adoptions of both unrelated and related children. Adoption declined in Germany following the 1978 peak, mostly because of a fall in domestic adoptions. Adoption declined in Sweden only after the 1975-1981 peak because from the 1960s to the 1970s the fall in domestic adoptions was compensated by a surge in inter-country adoptions, most of them from Asia. Adoption in France peaked in 1977; it stagnated from the late 1970s to the mid-2000s, while the fall in domestic adoptions was compensated by a surge in inter-country adoptions; and it decreased since then. Italy is the only country where child adoptions have become more frequent recently from the 1983 law to at least the late 2000s.

To better understand the reasons for these patterns across countries and across time I now address the main types of adoptions separately: domestic adoptions of unrelated children (Section 4), domestic adoptions of related children (Section 5) and inter-country adoptions (Section 6). The vertical axis of Figures 2 to 5 is half that of Figure 1.

\section{Domestic Adoptions of Unrelated Children}

Most adopters of unrelated children are childless - sterile - married couples in their thirties or forties, although a few are also (mostly female) singles. In England and Wales, when adoption was allowed for the first time in 1927, $85 \%$ of adopters were married couples adopting jointly (Rossini 2014, p. 98-99). In France as early as the 1950s sterile couples usually preferred to conceive a child through artificial insemination rather than adopt, however, because insemination raised fewer heredity problems and it made it easier for sterile couples to hide that their child was not both parents' biological child (Cahen 2013). Today, most adopters of domestic unrelated children adopt only after in vitro fertilization has failed (Fisher 2003). 
Most unrelated adoptees were legally or illegally abandoned children, although a few were also orphans or neglected and abused children who were removed from their birth family (Howell 2009). Most of the abandoned children were born illegitimate. In England and Wales in 1927, two thirds of all (unrelated and related) domestic adoptees were illegitimate (Rossini 2014, p. 98-99). And from the 1960s to 1975 close to $90 \%$ of domestic unrelated adoptees were born illegitimate (this proportion later decreased to $70 \%$ in 1985) (Selman 2006a). Similarly, in France from the 1950s to the 1970s, $90 \%$ of full domestic adoptees were born illegitimate and $50 \%$ to $70 \%$ were abandoned children from public foster care - only 5 $\%$ were orphans (Marmier-Champenois 1978). Today, many adoptable children have "special needs", i.e. are ill, disabled, or relatively old.

Until approximately the 1960s, in a context without reliable contraception or induced abortion and in a context in which illegitimacy was seen as proof of parents' loose morality, most birth mothers were poor single women who abandoned their illegitimate child to avoid personal and family shame (Bardet 1987). Given how economically difficult it was for a single mother to raise a child on her own, birth mothers also abandoned the child to preserve their own - and perhaps also the child's - life chances. In the early $20^{\text {th }}$ century, many if not most single mothers and birth mothers of abandoned children were young, recent migrants to the city working as servants (Laslett et al. 1980; Fauve-Chamoux 2009). As they were deprived of support networks and they were fired if they gave birth to a "shameful" child, they had to choose between their child and their work (Tilly et al. 1992). In France from the 1870 s to the 1920 s, poor single mothers abandoned their illegitimate child to hide their nonmarital pregnancy from their family and to avoid family shame - or they abandoned it on their parent' request to "repair" their fault and keep their chances of marrying an honorable man (Rivière 2015).

\subsection{Differences across Countries}

Until the 1970s, domestic adoptions of unrelated children were much more frequent in England and Wales and in Sweden than in Germany or France, let alone Italy (Figure 2). Strikingly, in the 1960s domestic adoptions of unrelated children in England and Wales were three times more frequent than in Germany and ten times more than in France. 


\section{Figure 2. Domestic adoptions of unrelated children per 100,000 people in Western Europe, 1923-2014}

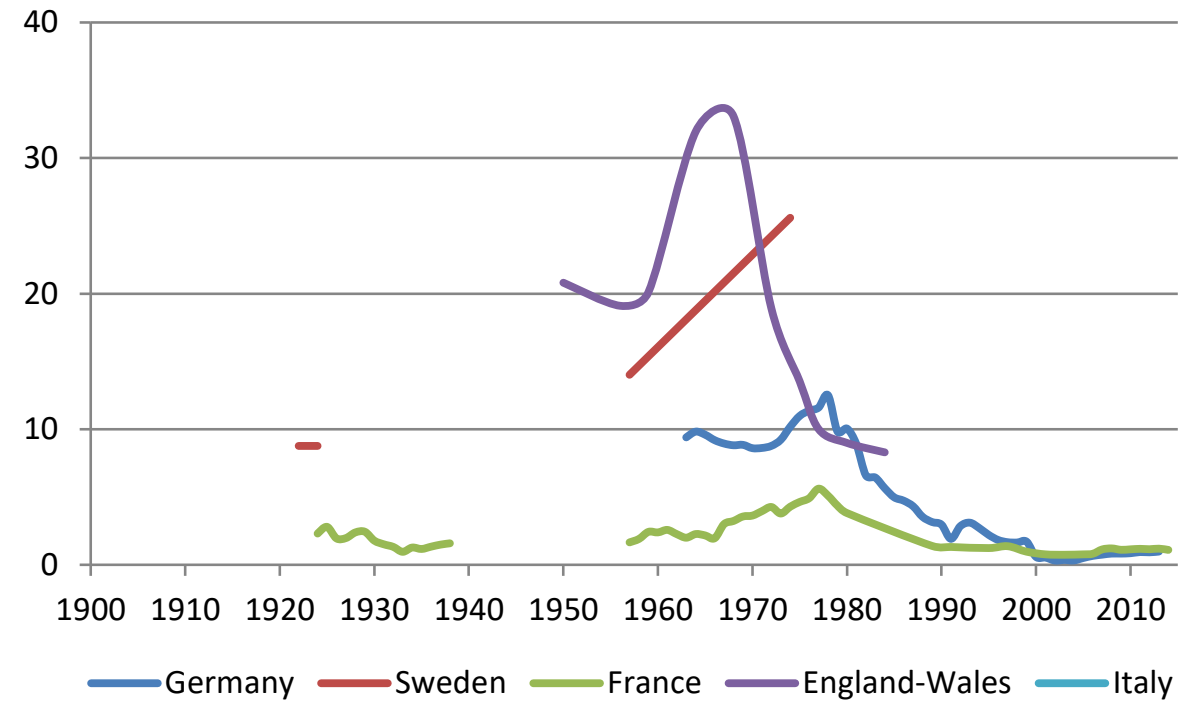

Sources: see Table 3 .

German data are slightly overestimated from 1963 to 1981 (they include not only domestic but also inter-country adoptions of unrelated children). Swedish data are not observed but estimated hypothesizing that the share of domestic adoptions which were unrelated adoptions was the same in all of Sweden as it was in Stockholm (on the 10 to $15 \%$ of all Swedish adoption cases that were handled in Stockholm courts, see Lindgren 2006, p. 33-35). French data are slightly overestimated from 1924 to 1938 (they include adoptions of related adults) and slightly underestimated from 1957 onwards (they include only full child adoptions from state foster care, not other full adoptions of unrelated children or simple adoptions of unrelated children). English data from 1950 to 1956 are maximum estimates. No Italian data is available.

What could explain such differences between on the one hand England and Wales and Sweden, and Germany, France and Italy on the other? Let us address some of the possibilities. It is unlikely that the relative frequency of adoptions in England and Wales was due to "supply-side" factors such as a higher birth rate, a higher share of illegitimate births or a higher number of orphans. England and Wales simply did not have a higher birth rate or a higher illegitimacy rate than most other Western European countries in the 1960s (Appendix, Figures A and B). Perhaps English single mothers abandoned their illegitimate children more often. Although we lack comparative data on this matter, it should be noted that from the $16^{\text {th }}$ to the $19^{\text {th }}$ centuries child abandonments were less frequent in Northern countries such as England and Wales than in Southern countries such as France and Italy (Bardet 1987; Hunecke 1991; Bardet and Faron 1996). Sweden did have a higher share of illegitimate births compared to other Western European countries across the whole $20^{\text {th }}$ century (Appendix, Figure B), but since it experienced a shortage of adoptable children as early as the 1950s (Lindgren 2006), it is unlikely that many of the children born out of wedlock were given up for adoption. Still another possibility would be that English private adoption agencies, which were especially active until the 1960s, favored adoptions more than public foster care, perhaps because such agencies are usually paid by the adoption. All these possibilities deserve future research. However, given that until the 1960s each country almost certainly had more children available for adoption than adoption applicants (see Figure 3 on Germany), the higher child adoption incidence in England and Wales and Sweden must have been mainly "demanddriven." 
It seems unlikely that the higher frequency of domestic adoptions of unrelated minors in England and Wales was due to such demand-side factors as a higher share of married couples who were childless. Indeed, among women born in the 1930s and 1940s (those who had children or adopted them from the 1950s to the 1970s), the proportion that remained childless was highest in Italy $(15 \%)$ and Sweden (13\%), it was average in England and Wales and Germany (11\%) and lowest in France (8 \%) (Appendix, Figure C; Rowland 2007; Tanturri et al. 2015, p. 10). Sterile married couples may also have been more willing to adopt in England and Wales and Sweden. Perhaps in richer countries more of the childless couples could afford a child - the richest Western European country was the United Kingdom until the 1940s and Sweden in the 1960s and 1970s (Appendix, Figure D). Living in a city might also have made it easier to hide that one's child was adopted - and the most urbanized Western European country was the United Kingdom from the early $20^{\text {th }}$ century to the 1960 s and Sweden from the 1960s to the 2000s (Appendix, Figure E). However, until the interwar years Sweden was the least urbanized country and its adoption rate was already three times higher than in France. Understanding why England and Wales and Sweden adopted more than other Western European countries might require gathering individual data detailing which couples in each country applied for adoption and finally adopted a child.

\subsection{Evolution across Time}

In most Western European countries domestic adoption of unrelated children has become more frequent from the interwar period to the 1950s and the 1960s (Figure 2). This increase is likely due to some kind of rising demand for children by childless married couples, rather than rising supply. Indeed, in most Western European countries until the 1960s there were far fewer adoption candidates (demand) than foundlings or adoptable children (supply). For instance, in Germany in 1928 only $0.4 \%$ of the children in German Youth Bureaus were adopted annually (Benninghaus 2013). Actually, there were fewer adoption applicants than adoption earmarked minors in Germany well into the 1960s (Figure 3). There were also fewer adoption candidates than adoptable children in Sweden until the 1950s (Lindgren 2006). Similarly, in France in the 1950s and 1960s only $1 \%$ to $4 \%$ of adoptable children (pupilles de l'État) were adopted annually (Verdier 1986).

Why did the demand for adopting unrelated children increase from the interwar years to the 1950s and 1960s? The reason was probably not a rise in the number of childless people. On the contrary, the share of women who remained childless reached its minimum among women born in the 1930s and 1940s, who adopted from the 1950s to the 1970s (Appendix, Figure C). Did childless married couples tolerate childlessness less, perhaps because in a period of higher fertility and increasing demand for the emotional component of parenthood, remaining childless became more painful? Did adopters tolerate the inclusion of illegitimate children into their own family more, perhaps because anonymous cities made it easier to hide a child adoption from neighbors and schools (Appendix, Figure E)? Because illegitimacy was considered as shameful in Western Europe as well as in the United States (Carp 1998) until at least the 1960s, many if not most adopters did not tell anyone - not even the adoptee - that they had adopted. In addition, parent-child matching usually aimed at making it plausible that the adoptee was born from the adopters (Lindgren 2006).

The erosion of heredity fears may be another possible reason for the increase in the demand for adoptions of unrelated children until the 1960s or 1970s. Indeed, it seems that adopters came to view "bad blood" as less important for adopted children's outcomes and well-being, compared to the power of love to construct strong family bonds. Until the 1940s congenital syphilis, which was transmitted from pregnant women, especially prostitutes, to the fetus, could not always be reliably detected in infants and it was widely (although wrongly) believed to be hereditary, for which there could be no cure. In this context, 
suspicions against adopting might not be surprising. In Germany in the 1930s worries about the hereditary traits and health of illegitimate children led adoption agencies to make sure that only healthy children could be adopted (Benninghaus 2013). Since the 1940s, we know that congenital syphilis is not hereditary: antibiotics such as penicillin treat it effectively. This may have contributed to reduce the risk or uncertainty of the adoption of unrelated children. More generally, in most countries feeble-minded children were considered unadoptable and some eugenicists even considered that adopters facilitated the reproduction of illegitimate children's poor intelligence, bad temperament and morality, anti-social behavior, etc. (Herman 2012).

\section{Figure 3. Adoption applicants (demand) and adoption earmarked minors (supply) per 100,000 people in Germany, 1950-2013}

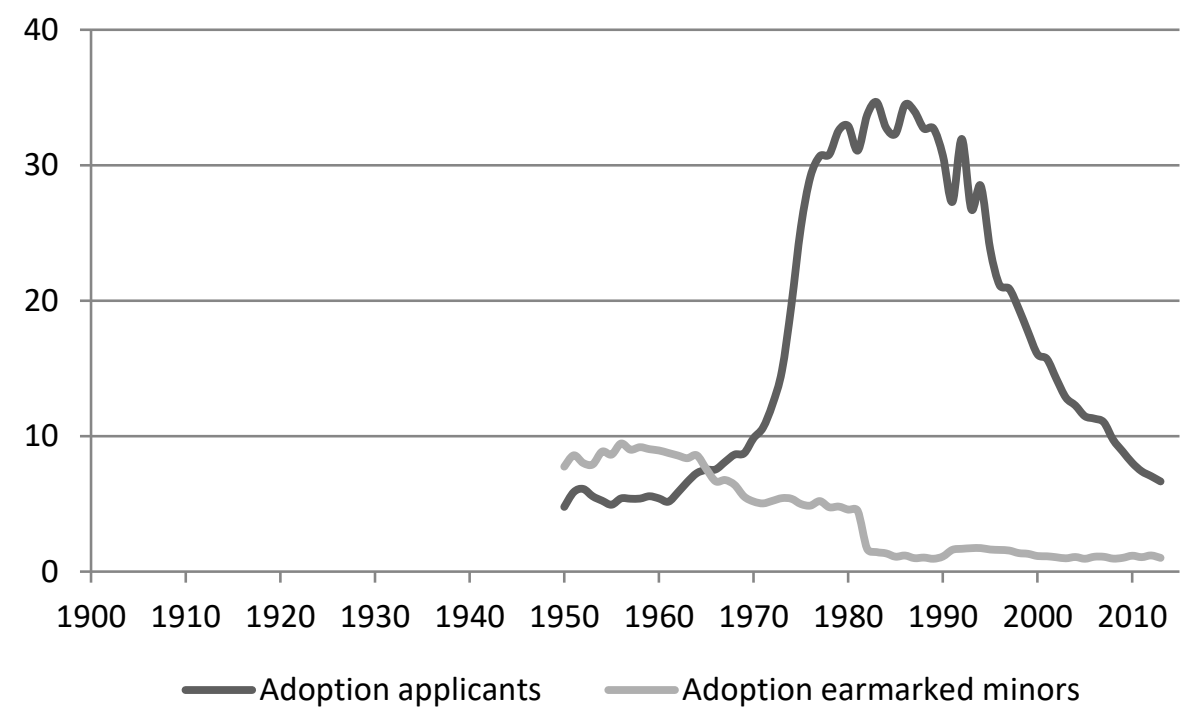

Source: Statistisches Bundesamt 2015

Domestic adoptions of unrelated children have become less frequent since the late 1960s in England and Wales and since the late 1970s in Sweden, Germany and France. This is usually explained by a fall in the supply of adoptable children. Indeed, the easier access to contraception (Appendix, Figure F) and induced abortion reduced the number of unwanted conceptions and births and the number of abandoned infants. In addition, Western European countries' family laws stopped discriminating against illegitimate children and welfare states even started supporting single-parent families, further reducing single mothers' tendency to abandon their non-marital children. Today in Western Europe the annual number of abandoned children is very low and keeps decreasing.

The eroding suspicion against illegitimate children's hereditary problems, the receding fear of social stigma, and public policies favorable to adoption probably contributed to the considerable increase in the demand for the adoption of domestic unrelated children. Indeed, despite the rise in assisted reproductive technologies (in vitro fertilizations were made available for the first time in England and Wales in 1978), the demand for adoption kept increasing. However, in the absence of abandoned children no supply could meet this demand. In Germany the shortage in adoptable children grew strongly in the 1970s and 1980s and has remained large since then (Figure 3). In France and Italy too, from the 1990s to the 2010s there were three to twelve times more adoption candidates than adoptable children (Mignot 2015b). In France, while in the 1950s and 1960s only $1 \%$ to $4 \%$ of adoptable children were adopted annually, this proportion increased to $4 \%$ to $10 \%$ in the 1970 s and to $20 \%$ to $35 \%$ since the 2000s (Observatoire national de l'enfance en danger 2007-2016). Not all legally adoptable children are adopted, however, because few candidates are willing to 
adopt older children and because social workers believe it sometimes is in children's interest to remain with the foster family they love.

In the late $19^{\text {th }}$ century some foster parents in need of workers preferred to foster adolescents. However, as adoptions of unrelated children were motivated more and more by emotional instead of instrumental reasons, adoption candidates' preferences shifted from adolescents to children. In the interwar years many adopters in Germany (Benninghaus 2013) and England and Wales (Keating 2009) preferred children around two or three years old, an age at which they supposedly had forgotten their birth parents and their health could be evaluated with precision. From the 1940s, once infant mortality had dropped, more and more adopters preferred infants to children because they can attach more easily (Keating 2009, p. 187). Thus in England and Wales " 36 per cent of all adoptions in 1951 were of infants under twelve months, 51 per cent in 1968" (Keating 2009, p. 207). From the 1970s, however, the shortage of adoptable infants meant that adopters could not always act on their preferences. In England and Wales, the share of (unrelated or related) domestic adoptees who were under 5 at adoption went from $50 \%$ in 1974 to $31 \%$ in 1995 (though it increased to $65 \%$ in 2012) (Office for National Statistics 2013). In France, the mean age of adopted children increased from 1.3 years in the 1950s to 3.2 years in the 1990s (Halifax 2005), and is even higher now.

Many adoption candidates also prefer to adopt a girl instead of a boy, perhaps because girls have a reputation for being more emotionally rewarding. In Germany as early as the 1920s, there was a higher demand for girls and they were in shorter supply (Benninghaus 2013). In England in the 1920s and 1930s, "Every reference to a preferred gender in adoption [...] makes it clear that girls were markedly favoured above boys, even if adopters settled for what was available" (Keating 2009, p. 203). Despite this preference, close to $50 \%$ of domestic adoptees were boys, whether in France from the 1950s to the 2000s (Mignot 2015a; Belmokhtar 1996; Belmokhtar 2009), England and Wales from the 1980s to the 2010s (Office for National Statistics 2013), or Germany (Statistisches Bundesamt 2015) and Sweden (Statistiska centralbyrån 2016) from the 1990s to the 2010s.

\section{Domestic Adoptions of Related Children}

Most adopters of related children are step-fathers adopting their step-child following their marriage with the child's single, divorced, or widowed mother (Goldscheider 2015). For instance, in England and Wales "in 1955, of the 10,341 illegitimate children adopted, 111 were adopted by their parents jointly, 19 by their father with a partner, 3,000 by their mother with a partner, 18 by their father on his own and 87 by their mother on her own" (Keating 2009 , p. 140). In Germany in the 1990s and the 2000s more than $90 \%$ of adoptions of related people are step-parent adoptions. In France in the 2000s too, most related children are adopted by their often-childless step-father following his marriage with the child's divorced mother (Belmokhtar 2009). Step-parent adoptions may benefit illegitimate children with the aim of legitimizing the child; or they may benefit legitimate children following their mother's divorce or widowhood and remarriage, with the aim of giving the child the same surname as the step-family. Other kin might adopt, too. In France in the interwar period, approximately $45 \%$ of adoptees were adopted by their aunt, uncle, step-parent or another relative (Mignot 2015a). Some adopters even adopt their own illegitimate children to pass on their inheritance as to legitimate children. Today, a few of the step-parents who adopt their step-child may be members of same-sex couples, mostly couples of women.

\subsection{Differences across Countries}

Until the 1970s domestic adoptions of related children were more frequent in Sweden and in England and Wales than in France, Germany or Italy (Figure 4). Even assuming that in interwar Germany all child adoptions (Figure 1) were of related children 
(Verwandtenadoptionen) (Mouton 2005), adoptions of related children would still be 1.5 times less frequent in interwar Germany than in Sweden. Above all, in the 1960s domestic adoptions of related children were three to four times more frequent in Sweden and in England Wales than in Germany, let alone France or Italy.

Figure 4. Domestic adoptions of related children per 100,000 people in Western Europe, 1923-2013

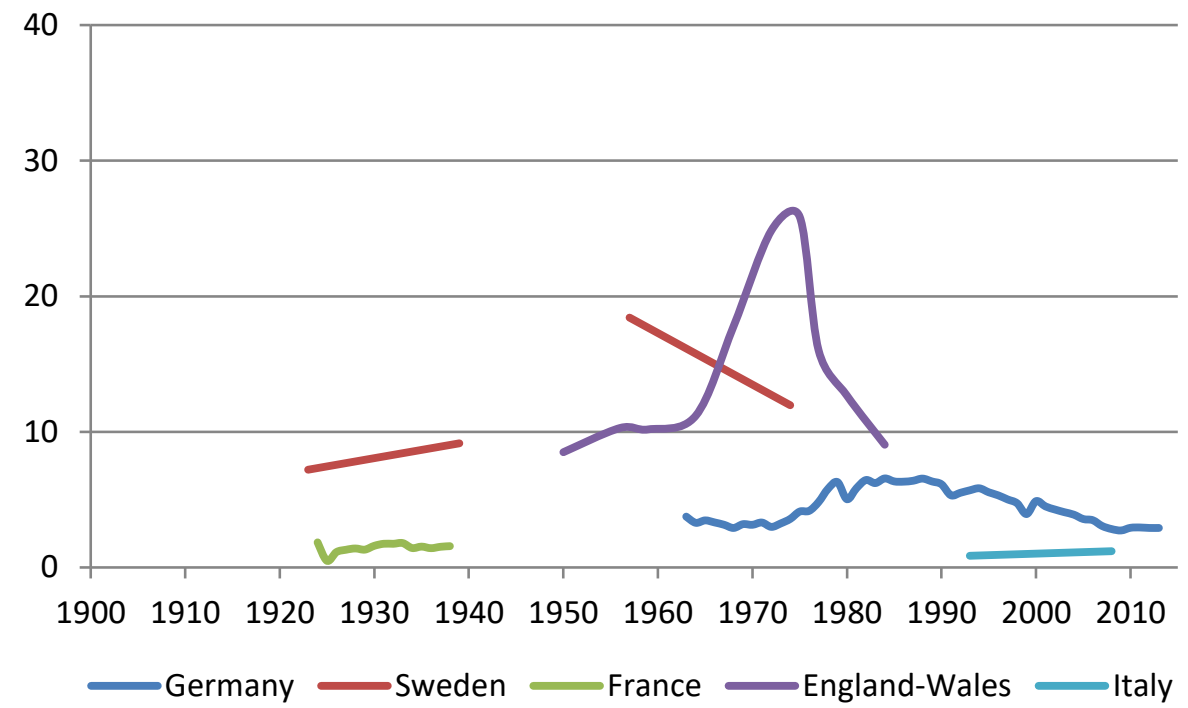

Sources: see Table 3 .

German data are slightly overestimated from 1963 to 1981 (they include not only domestic but also inter-country adoptions of related children). Swedish data are not observed but estimated hypothesizing that the share of domestic adoptions which were related adoptions was the same in all of Sweden as it was in Stockholm (Lindgren 2006, p. 33-35). English data from 1950 to 1956 are slightly underestimated (they include only step-parent adoptions). French data from 1924 to 1938 are slightly overestimated (they include adoptions of related adults).

What could explain such differences between on the one hand Sweden and England and Wales and on the other hand Germany, France and Italy? One possibility is that there were more step-parents and step-children living together in Sweden and in England and Wales. Indeed, since the 1950s Sweden has had the highest total divorce rate in Western Europe, before England and Wales; then come Germany and France; and Italy has by far the lowest divorce rate of the countries discussed here (Appendix, Figure G). While in England and Wales in the 1950s most adopted step-children's mothers were single mothers $(80 \%$ of adopted step-children were illegitimate), in the 1970s most adopted step-children's mothers were divorced (60 \% of adopted step-children were legitimate) (Masson et al. 1983, p. 1). Perhaps in Sweden and England and Wales single mothers married more often, which would have increased the number of step-parents and step-children living together. However, we simply do not know enough yet to explain this fact properly. In England and Wales the number of adoptions of related children peaked in the mid-1970s while the number of adoptions of unrelated children peaked in the late 1960s, which might indicate that these trends were driven by different processes. However, this does not tell us why English stepfathers adopted so many step-children. One major reason for step-parent adoption in England in the 1970s was the need to regularize all the relationships in the family following the birth of a child, and more particularly to have one surname for all family members once children were starting school (Masson et al. 1983, p. 16). 


\subsection{Evolution across Time}

In most Western European countries domestic adoptions of related children have become more frequent and then less frequent, the peak being probably in the 1950s in Sweden, in the 1970s in England and Wales and in the 1980s in Germany (Figure 4). Given the little information that is available, this trend is not easy to explain. The increase in the number of adoptions of related children until at least the 1950s may be due to factors such as the increase in the number of war orphans or fatherless children who were adopted by their aunt or uncle or step-parent. In England and Wales the Adoption Act 1958 also facilitated adoption by parents and step-parents (Masson et al. 1983, p. 20). When, especially in the 1960s and early 1970s, the number of step-parent adoptions increased in England and Wales, this was largely due to the increase in step-father adoptions following the mother's divorce, not following a death or step-parent adoptions of illegitimate children (Masson et al. 1983, p. 1). Among step-children adopted between 1975 and 1978, more than half (51\%) had divorced parents (36\% were illegitimate, $9 \%$ had lost a parent and $4 \%$ were in a mixed category) (Masson et al. 1983, p. 1).

The fall in the number of adoptions of related children in England and Wales since the mid-1970s is clearly due to the Children Act 1975, which sought to partly replace step-parent adoption with guardianship or custodianship in order not to cut the child from its other parent, usually its father. This law directly contributed to the fall in step-child adoption applications and orders, especially post-divorce adoptions (Masson et al. 1983). More generally, however, the considerable increase in divorce frequency in Western Europe since the early to mid 1960s (Appendix, Figure G) does not seem to have increased the number of step-parents adopting a step-child. This is likely because most Western European adoption legislations now want to avoid step-child adoptions which risk severing the legal and psychological link between the child and its father (United Nations 2009). From the 1970s single motherhood also became more often chosen and better accepted both legally and socially, so single mothers may now try less hard to find a husband to educate their child (Rivière 2015). The equalization of legitimate and illegitimate legal links may also have reduced the benefits of adopting a child in order to legitimize it. This might be why in England and Wales the share of domestic related adoptees who were born illegitimate went from $66 \%$ in 1960 to $40 \%$ from the early 1970s to the early 1980s (Selman 2006a).

\section{Inter-country Adoptions of Children}

Inter-country adoptions of children should be distinguished from child migration (Kershaw and Sacks 2008; Stuchtey 2013, p. 51; Jablonka 2007) and forced migration programs such as the Nazi Lebensborn (Fehrenbach 2010, p. 183-184) but also from child rescue programs (Hübinette 2003; Hübinette and Tigervall 2006; Hübinette 2009). Although as early as the 1930s British "children had been sent from adoption societies to adoptive parents in Holland, France, Belgium, Switzerland, Norway and the USA" (Rossini 2014, p. 111-112), inter-country adoptions started mostly in the wake of the Second World War. That is when 500 abandoned children from Germany were sent to Sweden for adoption (Hübinette 2003). Between 1946 and 1951, another 500 abandoned "occupation children" born from French occupying troops in Germany and German women were sent to France for adoption (Fehrenbach 2010, p. 187-189; Denéchère 2011). Some German war orphans were also adopted in the United States (Weil 1984). Germany is the only Western European country from which a substantial number of inter-country adoptions occurred (Annex, Figure H). In France, a colonial country, humanitarian adoptions of war orphans and abandoned children increased following the 1955-1975 Vietnam wars (Denéchère 2011). Adoptions from South Korea to Sweden started in 1957 and in the 1970s both countries signed an agreement which facilitated inter-country adoption legal procedures (Hübinette 2003; Lindgren 2006). In 1976, 
South Korean president Park Chung-hee invited adopted Koreans from Scandinavia to a motherland tour. Inter-country adoption procedures are now regulated by the Hague Convention on Protection of Children and Co-operation in Respect of Intercountry Adoption which all Western European countries have signed and ratified since the 1990s and 2000s (Hague Convention on Protection of Children and Co-operation in Respect of Intercountry Adoption 2016).

\subsection{Differences across Countries}

Since the 1960s, inter-country adoptions have been much more frequent in Sweden than in France or Italy, let alone Germany and England and Wales (Figure 5). In the 1980s, intercountry adoptions in Sweden were at least ten times more frequent than in any other Western European country. In the 2010s, inter-country adoptions are approximately thirty times more frequent in Sweden than in England and Wales.

Figure 5. Inter-country adoptions of children per 100,000 people in Western Europe, 1969-2015

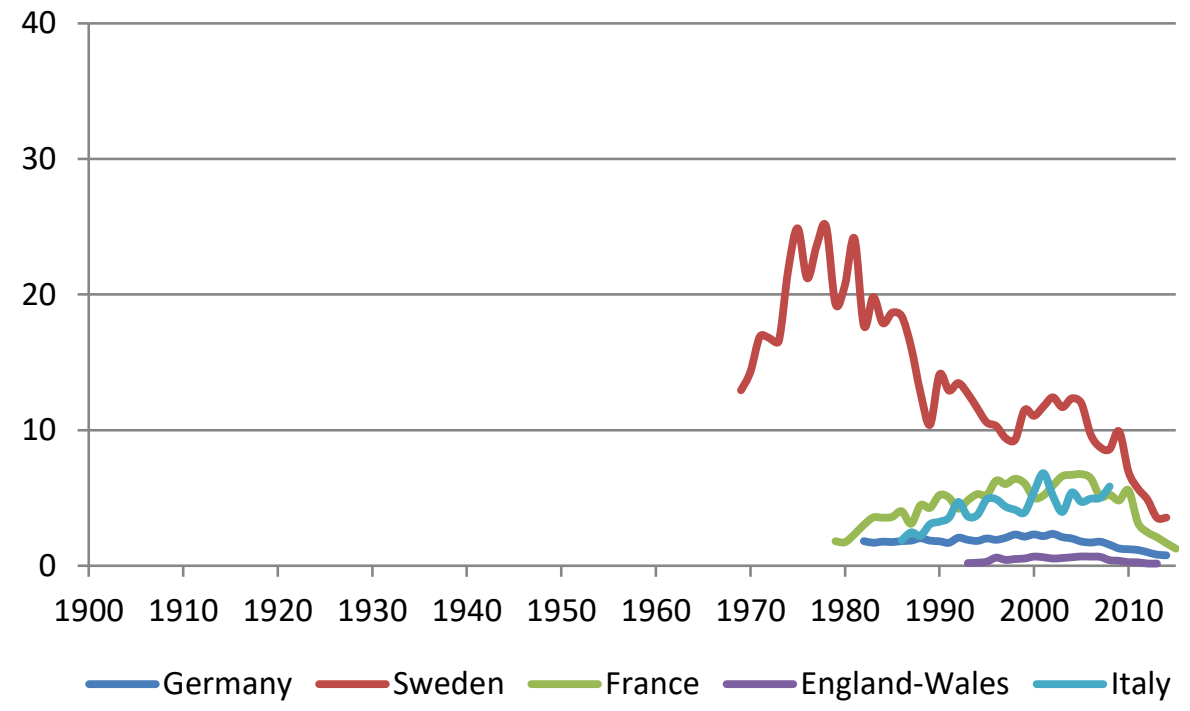

Sources: see Table 3 .

Why have Swedish couples adopted so many foreign children while English and Welsh couples have adopted so few? In Sweden as early as the late 1950s or early 1960s, adoption candidates faced a shortage of adoptable domestic children (Lindgren 2006). This triggered a demand for inter-country adoptions, which the Swedish government facilitated. To this day, the Swedish government provides inter-country adopters with a financial grant (O'Halloran 2015 , p. 779 ) that has been raised in 2016 . Sweden thus pioneered inter-country adoption and reached one of the world's highest rates of inter-country adoptions. In Sweden in the 2000s, "[j] ust under one thousand children are adopted annually, the majority from 30 or so countries, mostly from Asia. There are less than 200 domestic adoptions a year in Sweden, roughly 20 cases a year involving infants and an equal number involving children in foster care. Of the remainder, most involve the adoption of step-children" (Socialstyrelsen 2009, p. 14). Inter-country adoption, an act of solidarity with the Third World, became part of Sweden's self-image and reputation as one of the world's most liberal and progressive countries (Hübinette and Tigervall 2006; Lindgren 2006; Jonsson Malm 2010). "However from the end of the 1990s, the general public view of international adoption as an act of antiracism and solidarity, the adopted children as utopian bridges between cultures, and the adoptive parents as child rescuers, was suddenly challenged as adult adoptees and adoptive 
parents started to voice their own experiences in the form of the publication of memoir works and autobiographies." (Hübinette and Tigervall 2006)

In England and Wales, by contrast, adoption candidates did not face a similar shortage of adoptable domestic children, perhaps partly because since the 1980s high numbers of neglected or abused children were removed from their parents and placed for adoption (Mignot 2017). Therefore, there might never have been as much demand for inter-country adoption in England and Wales as in Sweden. In addition, the British government made intercountry adoption much more costly than domestic adoption (in both money and time) in order to have British - not foreign - children adopted and to reduce local authorities' care costs. Finally, memories of the forced migration of children cast doubt on the idea that inter-country adoption might be good for children. As a consequence, many British social workers believe that trans-racial adoption is often not in the child's best interests (personal communication from Julie Selwyn).

While differences in the incidence of inter-country adoptions between Western countries are impressive, there have also been differences in inter-country adoptees' countries of origin. (Information on the origins of inter-country adoptees to England and Wales and Germany since the 1970 s is hard to find, though.) Most inter-country adoptees to both Sweden and France in the 1970s and 1980s came from Asia (Hübinette 2001b; Ministère des Affaires étrangères 2016). However, while most inter-country adoptees to Sweden still came from Asia in the 2000s (Hübinette 2001b), only $25 \%$ of inter-country adoptees to France and fewer than $20 \%$ of inter-country adoptees to Italy came from Asia in the 2000s and 2010s (Ministère des Affaires étrangères 2016; Commissionne per le adozioni internazionali 2014). In France adoptees come more or less equally from all continents and in Italy adoptees from Eastern Europe now outnumber those from Asia. As a matter of fact many inter-country adoptees now are interracial adoptees, which raises some specific challenges for their psychological health and/or well-being, including possible self-esteem problems and ethnic identity conflicts (see Hjern et al. 2002, Dalen et al. 2008, Lindblad et al. 2010 and Ma forthcoming on Sweden; Halifax and Labasque 2013 on France; Ferrari and Rosnati 2013, Rosnati and Ferrari 2014 on Italy; Clarke 2014 on England; see also Hollingsworth 1997 and Juffer an IJzendoorn 2007 for meta-reviews of the literature).

\subsection{Evolution across Time}

Inter-country adoptions to France, Italy and Germany became more frequent until the mid-2000s (Figure 5), likely because the liberalization of contraception and induced abortion triggered a shortage of healthy domestic infants who were adoptable. In addition, as illegitimacy and adoption ceased to be shameful, this enabled parents to consider adopting visibly foreign children, which required parents to tell everyone that their children were adopted. This stands in stark contrast with adoption practices until then, which had largely been untold and even hidden. The replacement of domestic adoptions with inter-country adoptions from the 1960s or 1970s to the mid-2000s also made adoption more socially visible than it had ever been.

In Sweden the decrease in inter-country adoptions dates back to the late 1970s, which would require a specific explanation. In France, Italy and Germany inter-country adoptions have become much less frequent since the mid-2000s because the number of adoptable children has declined worldwide (Selman 2006b; Selman 2010; Selman 2012; Selman 2015; Mignot 2015c). The drop in mortality reduced the number of orphans; the number of children who are abandoned has also dropped as fertility declined, the stigma of illegitimacy eroded and social and child support policies were set in place in countries of origin; and more and more abandoned children in these countries are now adopted domestically. The signature and ratification of The Hague convention by more and more countries of origin further reduced 
the global supply of adoptable children. Most inter-country adoptees to Western Europe now have "special needs" such as in France and in Italy (Ministère des Affaires étrangères 2016; Commissionne per le adozioni internazionali 2014). Inter-country adoptees are older and older at adoption, which may raise concerns about children's integration into their host family and society. In France in 2015, $41 \%$ of inter-country adoptees were at least five years old at adoption, whereas that was the case of only $18 \%$ of them in 2005 . In Italy since the 2010 s a majority of inter-country adoptees are at least five years old at adoption, which was not the case in the 2000s. Similarly in Germany in 2014, $50 \%$ of inter-country adoptees were at least six years old at adoption (they were $36 \%$ in 1991 but $68 \%$ in 2005) (Statistisches Bundesamt 2015).

\section{Conclusion}

This chapter offered an overview of child adoption laws and practices since child adoption became legal in Western Europe. I have shown that Germany, Sweden, France, England and Wales and finally Italy introduced child adoption in their legal system in the early $20^{\text {th }}$ century for the welfare of vulnerable children, including war orphans and war babies. Since then, there has been growing social, political and legal support in favor of child adoption in the child's best interests - whatever the child's status: a kin, an abandoned child, an orphan or a foreigner. The incidence of child adoption increased from the early $20^{\text {th }}$ century to approximately the 1970s because of a rise in the demand for domestic adoptions of unrelated children. Further research needs to examine the specific reasons which led more and more sterile married couples to adopt unrelated children, in a context where most adoptions of unrelated children were designed to be emotionally fulfilling, but remained hidden. The incidence of child adoption also increased until the 1970s because of a rise in the demand for adoptions of related children. The incidence of child adoption has decreased since the 1970s, however, because the liberalization of contraception and induced abortion created a dearth of adoptable children, first domestically and then in foreign countries too. Child adoption in Western Europe has thus been directly impacted by the disappearance of child abandonment. In addition, step-child adoption is now avoided to preserve the link between the child and its father. Overall, child adoption incidence in Western Europe is approximately the same in the 2010 s as it was in the interwar period.

I have also shown that for most of the period since the early $20^{\text {th }}$ century the Swedes and the British adopted children much more frequently than Germans did, let alone the French or Italians. This long-term gap in adoption incidence is due to gaps in adoptions of both unrelated and related children. So why have the British and Swedish families been the most open to strangers to the family? If the North-South gradient is confirmed on all Western Europe, further research needs to examine the mechanisms behind it and how it fits with Western European family patterns. However, understanding this gap may require gathering individual data detailing which couples apply for adoption and finally adopt a child. More broadly, child adoption history now needs to include comparisons with Eastern European as well as non-European countries. In the U.S., since the 1950s there have been from 40 to 80 child adoptions per 100,000 people (Moriguchi 2012), which is more than in Sweden or England and Wales. In Japan since the 1950s adoptions have been even more frequent than in the U.S. but almost all adoptees are adults (Moriguchi 2010). Global patterns of adoption reveal underappreciated differences among some of the world's populations, thus complementing the usual analyses relying on marriage, fertility and migration. 


\section{Appendix}

Table A. Charateristics of Western European Countries

\begin{tabular}{|c|c|c|c|c|}
\hline & $\begin{array}{c}\text { Legal } \\
\text { system }\end{array}$ & $\begin{array}{c}\text { Language } \\
\text { family }\end{array}$ & $\begin{array}{c}\text { Majority } \\
\text { religion }\end{array}$ & Traditional family structure \\
\hline Germany & Civil code & Germanic & $\begin{array}{c}\text { Protestant / } \\
\text { Catholic }\end{array}$ & Stem \\
\hline Sweden & Civil code & Germanic & Protestant & Stem \\
\hline France & Civil code & $\begin{array}{c}\text { Italic } \\
\text { (Romance) }\end{array}$ & Catholic & Nuclear (North) and stem (South) \\
\hline $\begin{array}{c}\text { England- } \\
\text { Wales }\end{array}$ & $\begin{array}{c}\text { Common } \\
\text { law }\end{array}$ & Germanic & Protestant & Nuclear \\
\hline Italy & Civil code & $\begin{array}{c}\text { Italic } \\
\text { (Romance) }\end{array}$ & Catholic & $\begin{array}{c}\text { Nuclear (North and South) and } \\
\text { communitarian (center) }\end{array}$ \\
\hline
\end{tabular}

Source on traditional family structure: Kertzer 2001. 
Figure A. Live births per 1,000 people in Western Europe, 1900-2010

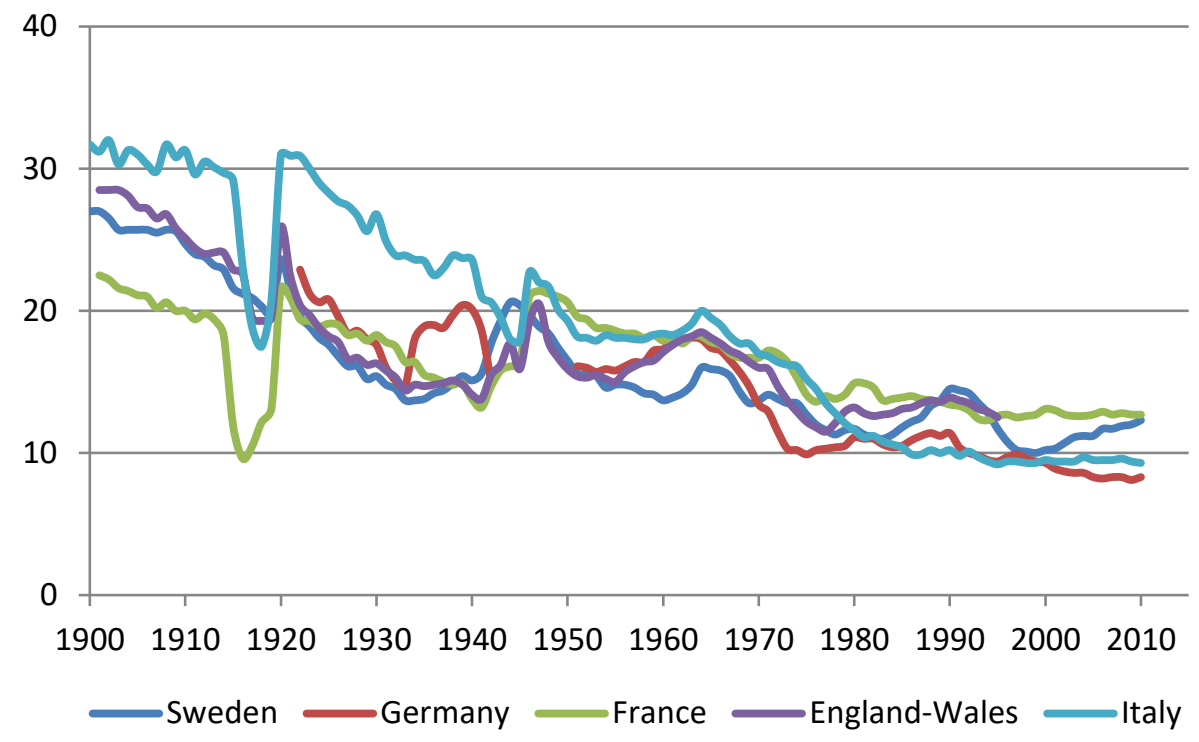

Source: Ined 2016.

Figure B. Share of births which are illegitimate in Western Europe, 1900-2014

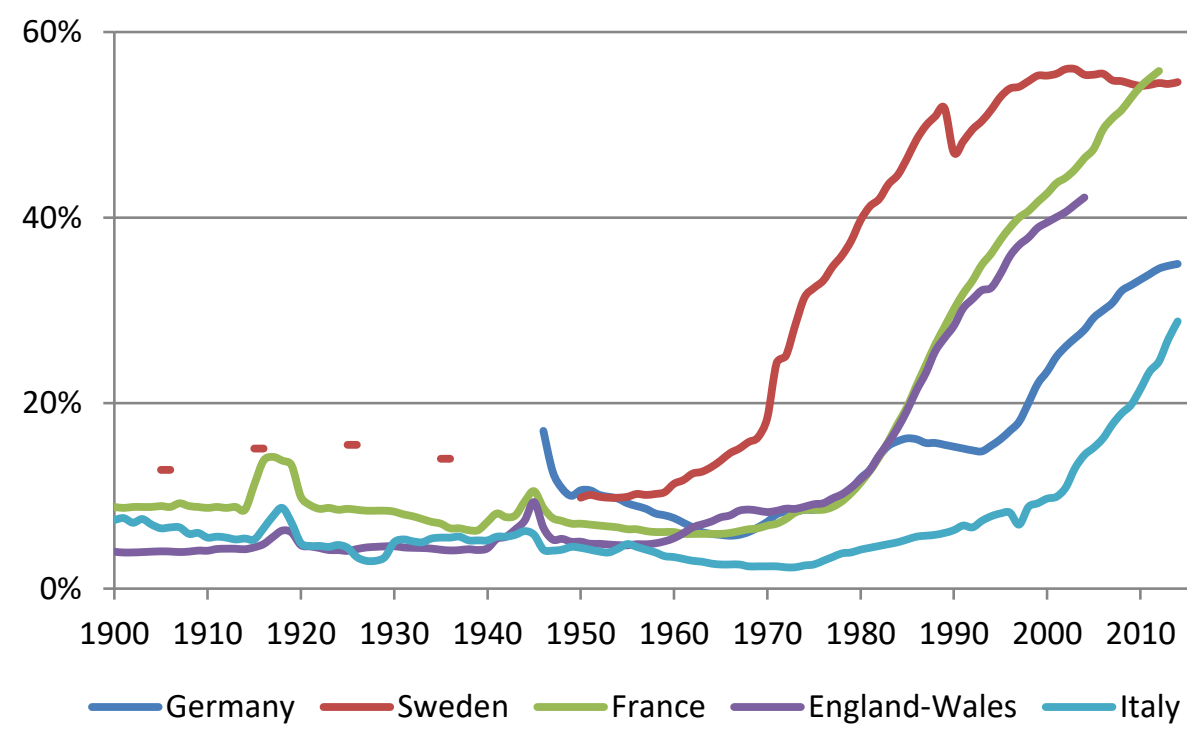

Source: Ined 2016; Eurostat 2016; Statistiska Centralbyrån 1969, p. 106. 
Figure C. Share of women who remained childless in Western Europe, per birth cohort 1930-1965

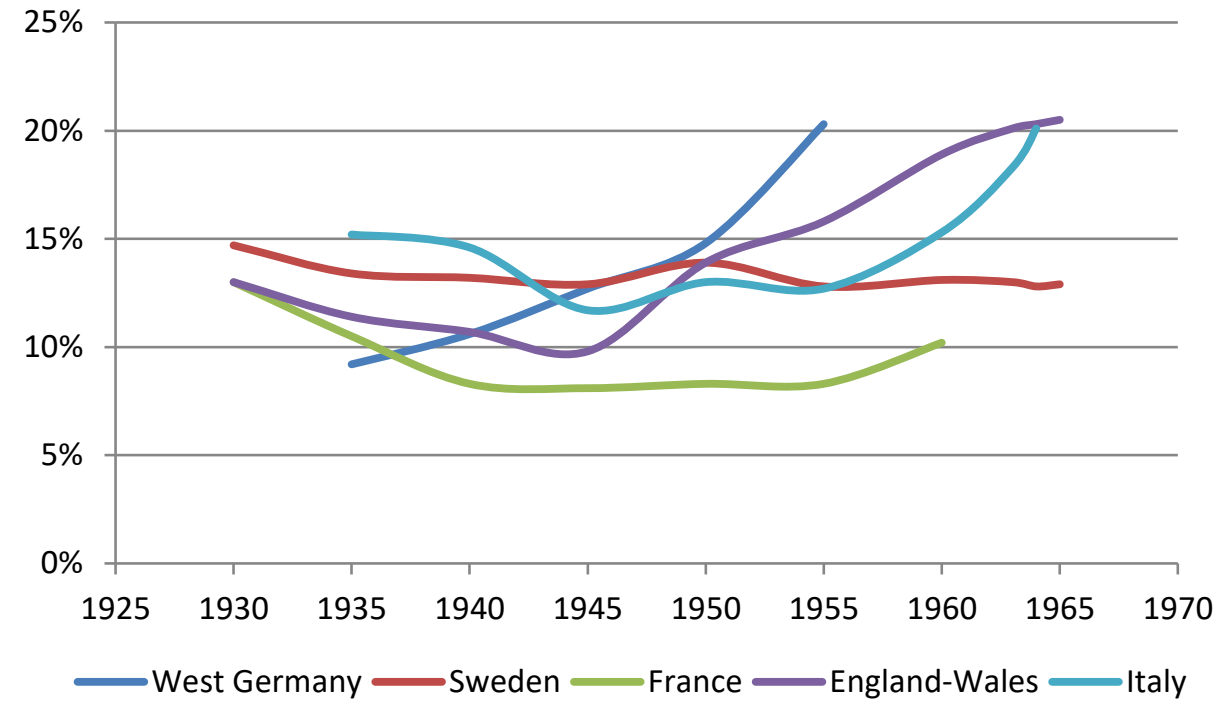

Source: Organisation for economic cooperation and development 2016.

Figure D. Gross domestic product per capita in Western Europe (in 1990 International Geary-Khamis dollars), 1900-2008

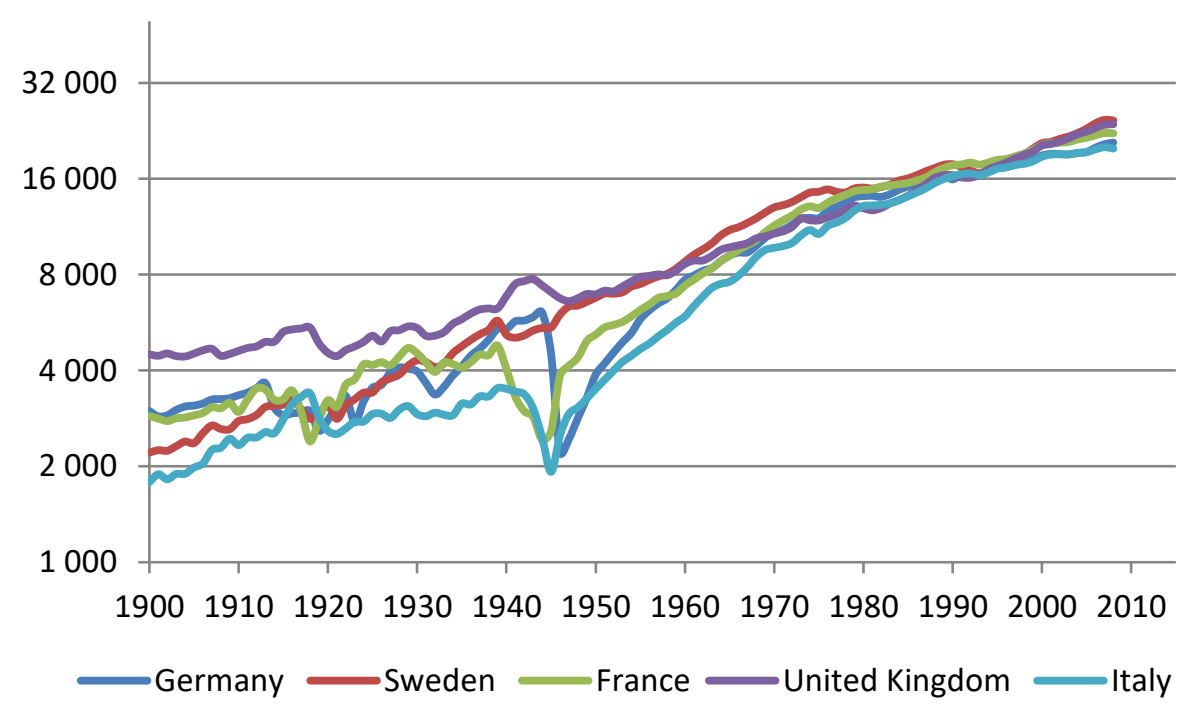

Source: Maddison 2003. 
Figure E. Urbanization rate in Western Europe, 1900-2015

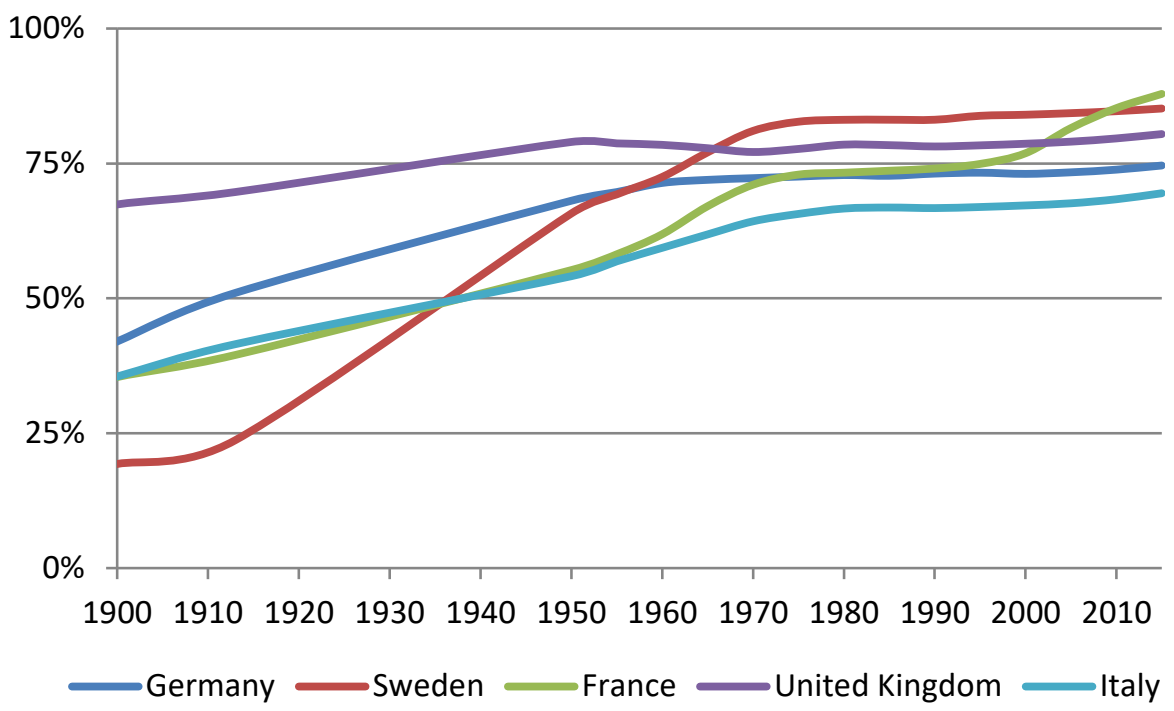

Sources: data on 1900-1913 are from Bardet and Dupâquier 1998, p. 221 (share of the population living in cities of 5,000 inhabitants or more); data on 1950-2015 are from United Nations Population Division 2015b (share of the population living in urban areas).

Figure F. Share of 15-44 women who take the contraceptive pill in Western Europe, 1968-1977

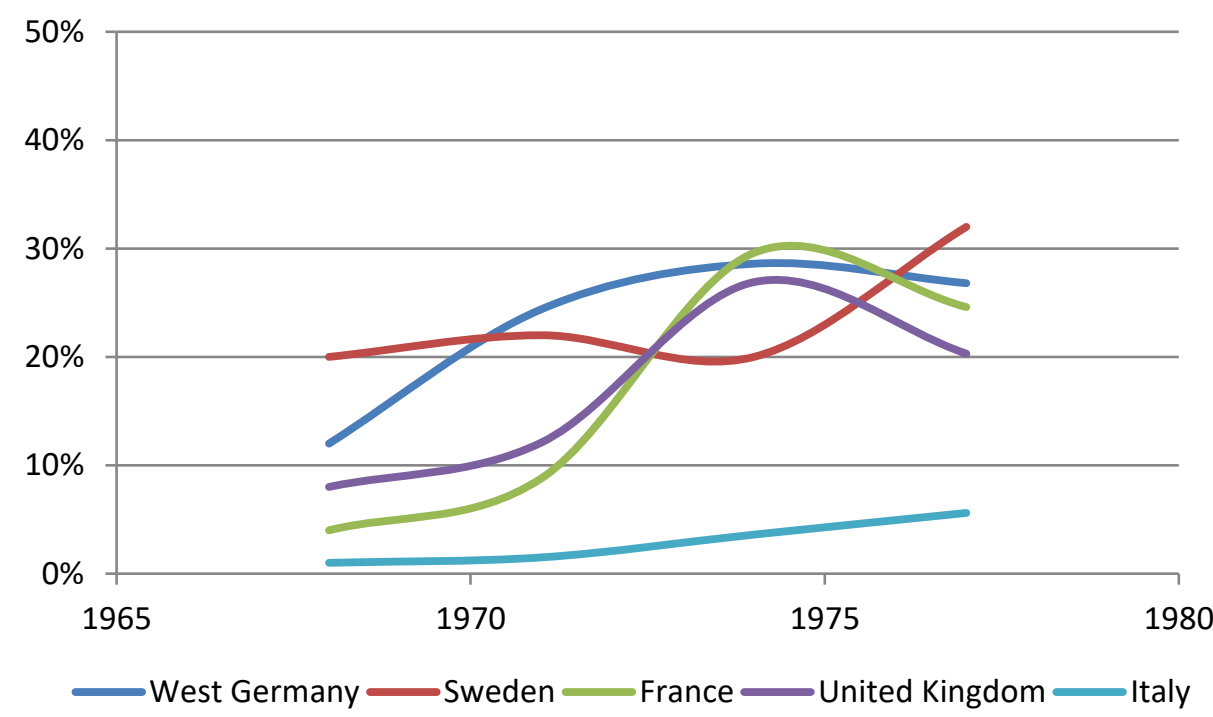

Source: Leridon et al. 1987. 
Figure G. Total divorce rate in Western Europe, 1946-2003

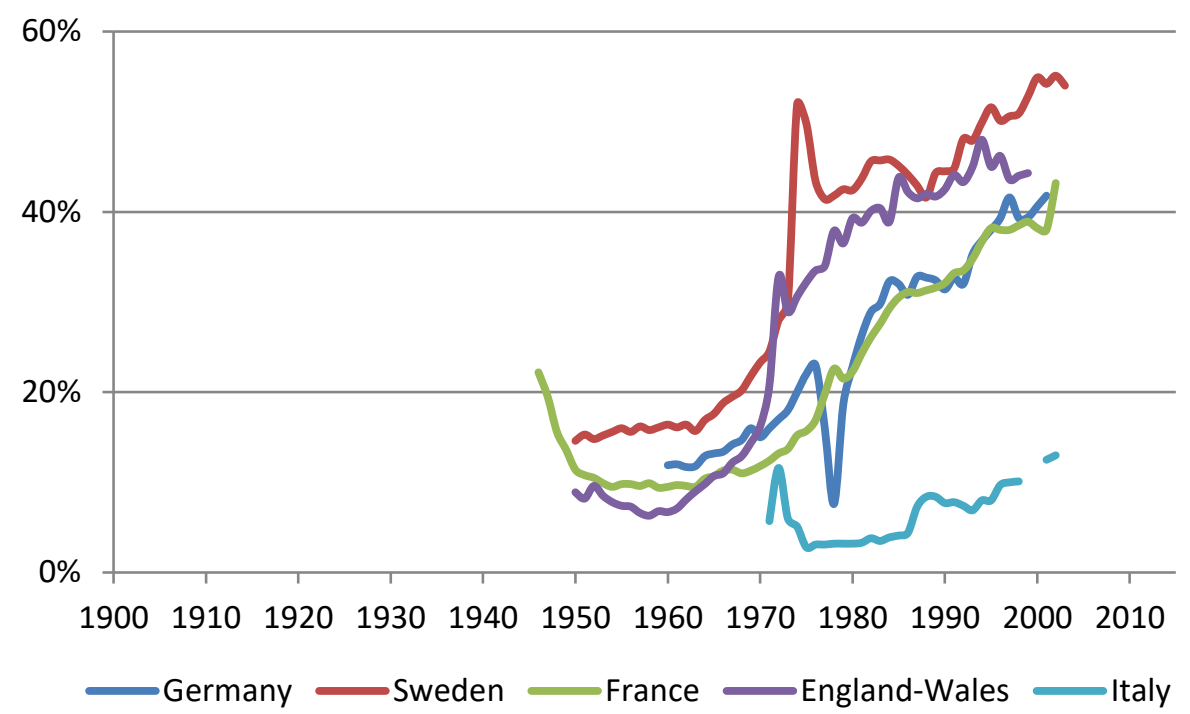

Source: Ined 2016.

Figure H. Inter-country adoptions of Western-German children (by foreigners) per 100,000 people in West Germany, 1950-1973

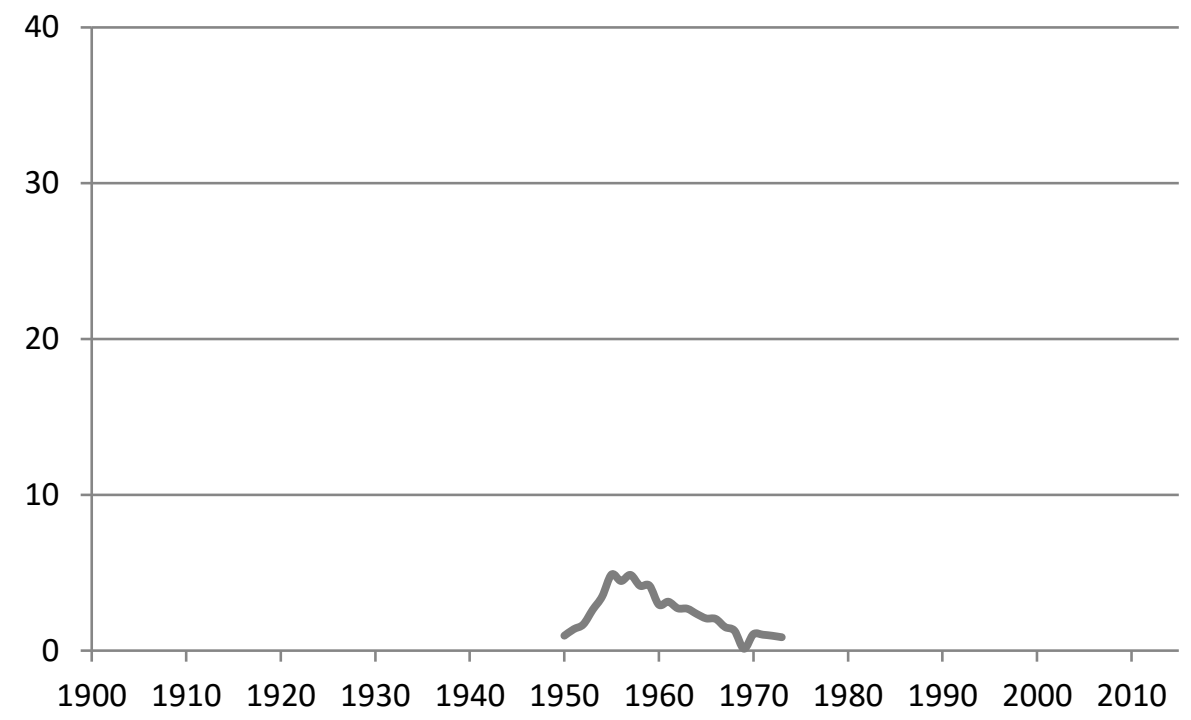

Source: Statistisches Bundesamt 1977, p. 64.

Field: from 1950 to 1953, inter-country adoptions from West Berlin are not included. 


\section{References}

A VISION OF BRITAIN THROUGH TIME. Population. 2009. Available at $<$ http://www.visionofbritain.org.uk>

ALFANI Guido, GOURDON Vincent (ed.). Spiritual Kinship in Europe, 1500-1900. Londres: Palgrave Macmillan, 2012.

ARIÈS Philippe, DUBY Georges (ed.). A History of Private Life. Cambridge : Belknap Press, 1990-1998.

AUSTRALIAN INTERCOUNTRY ADOPTION NETWORK. International Adoption Statistics. 2016. Available at <http://www.aican.org/statistics.php>

BACCARA Mariagiovanna, COLLARD-WEXLER Allan, FELLI Leonardo, YARIV Leeat.

Child-Adoption Matching: Preferences for Gender and Race. American Economic Journal: Applied Economics, 2014, 6(3), p. 133-158.

BARDET Jean-Pierre, DUPÂQUIER Jacques. Histoire des populations de l'Europe. Paris : Fayard, 1997-1999.

BARDET Jean-Pierre, FARON Olivier. Sull'infanzia abbandonata in età moderna. Storia dell'infanzia. 2. Dal settecento a oggi / ed. by Egle BECCHI and Dominique JULIA. Rome: Laterza, 1996, p. 100-131.

BARDET, Jean-Pierre. L'enfance abandonnée au cœur des interrogations sociales. Histoire, économie et société, 1987, 6(3), p. 291-299.

BECCHI Egle, JULIA Dominique (ed.). Storia dell'infanzia. 2. Dal settecento a oggi. Rome: Laterza, 1996.

BEHLMER, George K. What's Love Got to Do with It? "Adoption" in Victorian and Edwardian England. Adoption in America. Historical Perspectives / ed. by E. Wayne CARP. Ann Arbor: University of Michigan Press, 2002, p. 82-100.

BELMOKHTAR, Zakia. Les adoptions simples et plénières en 1992. Infostat justice, 1996, 46, p. 1-4.

BELMOKHTAR, Zakia. L'adoption simple et plénière en 2007 : des projets différents. Infostat justice, 2009, 106, p. 1-6.

BENICKE, Christoph. L'adoption internationale en droit allemand. Revue internationale de droit comparé, 2003, 55(4), p. 789-802.

BENNINGHAUS, Christina. Adoption - The Emergence of a New Reproductive Technology, Germany ca. 1890-1930. Unpublished paper, 2013.

BERGSTROM, Theodore C. A Survey of Theories of the Family. Handbook of Population and Family Economics / ed. par Mark K. ROSENZWEIG, Oded STARK. Amsterdam: Elsevier, 1997, p. 21-79.

BRAND, Elisabeth. Adoption-Italie. Revue internationale de droit comparé, 1985, 37(3), p. 631-651.

BURGUIÈRE, André. Un aussi long refus. Droit et pratique de l'adoption en France du XV ${ }^{\mathrm{e}}$ siècle au temps présent. Adoption et fosterage / ed. by Mireille CORBIER. Paris : De Boccard, 1999, p. 123-137.

BURGUIÈRE André, KLAPISCH-ZUBER Christiane, SEGALEN Martine, ZONABEND Françoise (ed.). A History of the Family. Cambridge: Polity Press, 1996.

CAHEN, Fabrice. Éléments pour une histoire de la lutte contre la stérilité involontaire (France, 1920-1982). Annales de démographie historique, 2013, 126(2), p. 209-228.

CARMICHAEL Sarah G., DILLI Selin, VAN ZANDEN Jan Luiten. Introduction: Family Systems and Economic Development. Economic History of Developing Regions, 2016, 31(1), p. 1-9.

CARP, E. Wayne. Family Matters: Secrecy and Disclosure in the History of Adoption. Cambridge : Harvard University Press, 1998.

CASELLI Graziella, VALLIN Jacques, WUNSCH Guillaume (eds.). Demography. Analysis and synthesis. A Treatise in Population. Paris: Academic Press, 2005.

CENTER FOR ADOPTION POLICY. Overview of German adoption law. 2016a. Available at <http://www.adoptionpolicy.org/pdf/eu-germany.pdf>

CENTER FOR ADOPTION POLICY. Overview of Swedish adoption law. 2016b. Available at $\langle$ http://www.adoptionpolicy.org/pdf/eu-sweden.pdf > 
CENTER FOR ADOPTION POLICY. Overview of English adoption law. 2016c. Available at $\langle$ http://www.adoptionpolicy.org/pdf/eu-england.pdf>

CENTER FOR ADOPTION POLICY. Overview of Italian adoption law. 2016d. Available at $<$ http://www.adoptionpolicy.org/pdf/eu-italy.pdf6>

CHASSAIGNE, Philippe. Un aspect peu connu de l'abandon d'enfants dans l'Angleterre victorienne : le baby farming. Annales de démographie historique, 1992, 1, p. 187-197.

CLARKE, Verity. The Voices of Mixed Ethnicity Adopted Children. Ethnic Identities, Experiences of Discrimination and Ethnic Socialisation. University of Bristol, 2014.

COALE Ansley J., COTTS WATKINS Susan. The Decline of Fertility in Europe. The Revised Proceedings of a Conference on the Princeton European Fertility Project. Princeton: Princeton University Press, 1986.

COMMISSIONE PER LE ADOZIONI INTERNAZIONALI. Dati e prospettive nelle adozioni internazionali. Rapporto sui fascicoli dal $1^{\circ}$ gennaio al 31 dicembre. Firenze: Istituto degli Innocenti, 2014. Available at <http://www.commissioneadozioni.it/media/143019/report_statistico_2013.pdf>

CONN, Peter. Adoption: A Brief Social and Cultural History. New York: Palgrave MacMillan, 2013.

CORBIER, Mireille. Introduction. Adoptés et nourris. Adoption et fosterage / ed. by Mireille CORBIER. Paris : De Boccard, 1999, p. 5-41.

Monica, HJERN Anders, LINDBLAD Frank, ODENSTAD Anna, RAMUSSEN Finn, VINNERLJUNG Bo. Educational attainment and cognitive competence in adopted men. A study of international and national adoptees, siblings and a general Swedish population. Children and Youth Services Review, 2008, 30, p. 1211-1219.

DASEN Véronique, LETT Didier, MOREL Marie-France, ROLLET Catherine. Dix ans de travaux sur l'enfance. Annales de démographie historique, 2001, 102(2), p. 5-100.

DENÉCHÈRE, Yves. Des enfants venus de loin. Histoire de l'adoption internationale en Allemagne. Paris : Colin, 2011.

DIEBOLT Claude, HAUPERT Michael (eds). Handbook of Cliometrics. Berlin : SpringerVerlag, 2016.

EUROSTAT

Eurostat

Database.

2016.

Available

at

$<$ http://ec.europa.eu/eurostat/data/database>

FAUVE-CHAMOUX, Antoinette. Domesticité et parcours de vie. Servitude, service prémarital ou métier? Annales de démographie historique, 2009, 117(1), p. 5-34.

FAUVE-CHAMOUX, Antoinette. Adoption, Affiliation, and Family Recomposition Inventing Family Continuity. The History of the Family, 1998, 3(4), p. 385-392.

FAUVE-CHAMOUX Antoinette, BRUNET Guy. L'enfant illégitime et ses parents. Tendances européennes et coloniales au XIXe siècle, au sein des modèles séculaires d'illégitimité. Annales de démographie historique, 2014, 127(1), p. 7-43.

FEHRENBACH, Heide. War Orphans and Postfascist Families. Kinship and Belonging after 1945. Histories of the Aftermath: The Legacies of the Second World War in Europe / ed. by Frank BIESS and Robert G. MOELLER. New York: Berghahn Books, 2010, p. 175-195.

FERRARI Laura, ROSNATI Rosa. Internationally adopted adolescents: How do they integrate ethnic and national identity? Italian Journal of Sociology of Education, 2013, 5(3), p. 45-61.

FINE, Agnès. Adoption et parrainage dans l'Europe ancienne. Adoption et fosterage / ed. by Mireille CORBIER. Paris : De Boccard, 1999, p. 339-354.

FISHER, Allen P. Still "Not Quite As Good As Having Your Own"? Toward a Sociology of Adoption. Annual Review of Sociology, 2003, 29(1), p. 335-361.

FLAUSS-DIEM, Jacqueline. Angleterre. Revue internationale de droit comparé, 1985, 37(3), p. 539-556.

FLORSCH, Michèle. Allemagne (République fédérale). Revue internationale de droit comparé, 1985, 37(3), p. 525-538.

GIUSTIZIA MINORILE. Dati statistici relativi all'adozione anni 2000-2013. Rome: Giustizia Minorile, 2014. Available

at <http://www.giustiziaminorile.it/statistica/approfondimenti/Adozione_Serie_Storiche.pdf>

GIUSTIZIA MINORILE. L'applicazione della Legge 4 maggio 1983 n. 184 "Disciplina dell 'adozione e dell'affidamento dei minori" negli anni 1993-1999. Analisi statistica. Rome: Giustizia 
<http://www.giustiziaminorile.it/statistica/approfondimenti/Adozioni_1993_99.pdf>

GLÄSSING, Helmut. Voraussetzungen der Adoption. Frankfurt am Main: Alfred Metzner Verlag, 1957.

GOLDSCHEIDER, Frances. Repartnering and Stepchildren. International Encyclopedia of the Social and Behavioral Sciences (Second Edition) / ed. by Neil J. SMELSER, Paul B. BALTES. Amsterdam: Elsevier, 2015, p. 430-433.

GOODY, Jack. The Development of the Family and Marriage in Europe. Cambridge: Cambridge University Press, 1983.

GOODY, Jack. Adoption in Cross-Cultural Perspective. Comparative Studies in Society and History, 1969, 11(1), p. 55-78.

GROTEVANT, Harold D., MCDERMOTT, Jennifer M. Adoption:-Biological and Social

Processes Linked to Adaptation. Annual Review of Psychology, 2014, 65, p. 235265.

GUTTON, Jean-Pierre. Histoire de l'adoption en France. Paris : Publisud, 1993.

HAGUE CONVENTION ON PROTECTION OF CHILDREN AND COOPERATION IN RESPECT OF INTERCOUNTRY ADOPTION. 2016. Available at $<$ https ://www.hcch.net/en/instruments/conventions/status-table/ ?cid=69>

HALIFAX, Juliette. Les familles adoptives en France. Histoires de familles, histoires familiales. Les résultats de l'enquête Famille de 1999 / ed. by Cécile LEFÈVRE and Alexandra FILHON. Paris : INED, 2005, p. 309-335.

HALIFAX Juliette, LABASQUE Marie-Véronique. Étude relative au devenir des enfants adoptés en France et à l'international. Rapport final. Amiens : CREAI de Picardie, 2013. Available at <http://www.adoption.gouv.fr/IMG/pdf_Rapport_final.pdf >

HERMAN, Ellen. Eugenics. The Adoption History Project, 2012. Available at <http://pages.uoregon.edu/adoption/topics/eugenics.htm>

HERMAN, Ellen. Kinship by Design. A History of Adoption in the Modern United States. Chicago: University of Chicago Press, 2008.

HEYWOOD, Colin. A History of Childhood. Children and Childhood in the West from Medieval to Modern Times. Cambridge: Polity, 2001.

HJERN Anders, LINDBLAD Frank, VINNERLJUNG Bo. Suicide, psychiatric illness, and social maladjustment in intercountry adoptees in Sweden: a cohort study. Lancet, 2002, 360(9331), p. 443-448.

HOLLINGSWORTH, Leslie D. Effect of Transracial / Transethnic Adoption on Children's Racial and Ethnic Identity and Self-Esteem. A Meta-Analytic Review. Marriage and Family Review, 1997, 25(1-2), p. 99-130.

HOWELL, Signe. Adoption of the Unrelated Child: Some Challenges to the Anthropological Study of Kinship. Annual Review of Anthropology, 2009, 38, p. 149-166.

HÜBINETTE, Tobias. Adoption. The Palgrave Dictionary of Transnational History. From the Mid-19 $9^{\text {th }}$ Century to the Present Day / ed. by Akira IRIYE and Pierre-Yves SAUNIER. New York: Palgrave Macmillan, 2009, p. 11-13.

HÜBINETTE Tobias, TIGERVALL Carina. Contested adoption narratives in a Swedish setting. Paper presented at the $2^{\text {nd }}$ International Conference on Adoption Research, University of East Anglia, Norwich, 2006.

HÜBINETTE, Tobias. The adopted Koreans of Sweden and the Korean adoption issue. The Review of Korean Studies, 2003, 6(1), p. 251-266.

HÜBINETTE, Tobias. Adopterade, institutionaliserade och fosterhemsplacerade barn i Sverige 1918-2001 i relation till antalet aborter, steriliseringar och IVF-födslar [Adoptees, institutionalized and foster children placed in Sweden 1918-2001 in relation to the number of abortions, sterilisations and IVF births]. 2001a. Available at <http://www.tobiashubinette.se/barn_sverige.pdf>

HÜBINETTE, Tobias. Anlända utomnordiska adoptivbarn (ålder 0-10 år) [Foreign adopted $\begin{array}{lllll}\text { children } & \text { (aged } & 0-10 & \text { years)]. Available }\end{array}$ <http://www.tobiashubinette.se/varldsdel_sverige.pdf>

HÜBINETTE, Tobias. Adopterade i Sverige exkluderande styvbarns och ensamadoptioner 1932-99 i relation till antal levande födda/år [Adopted in Sweden excluding stepchildren and alone 
adoptions 193299 in relation to the number of live births / year]. 1999. Available at كhttp://ww.tobiashubinette.se/fodelsear_sverige.pdf $>$

HUNECKE, Volker. Intensità e fluttuazioni degli abbandoni dal XV al XIX secolo. Enfance abandonnée et société en Europe, XIVe-XXe siècle. Rome: École Française de Rome, 1991, p. 27-72.

INED. Base de données des pays développés. 2016. Available at <https://www.ined.fr/fr/toutsavoir-population/chiffres/bases-donnees/donnees-pays-developpes/>

ISTAT. Serie storiche. Tavola 6.9 Provvedimenti giudiziari in materia di stato delle persone Anni 1891-2008 (valori assoluti). Adozioni di minori (di cui: adozioni di minori stranieri); Adozioni ordinarie. 2011.

Available

$<\mathrm{http} / / /$ seriestoriche.istat.it/index.php?id=7\&user_100ind_pi1\%5Bid_pagina\%5D=49\&cHash=66f9eb 5b9dc25bcee546ed696f1da59a>

JABLONKA, Ivan. Enfants en exil. Transfert de pupilles réunionnais en métropole (19631982). Paris : Seuil, 2007.

JABLONKA, Ivan. Ni père ni mère. Histoire des enfants de l'Assistance publique (1874-1939). Paris : Seuil, 2006.

JONSSON MALM, Carolina. Internationella adoptioner och familjens gränser [International adoptions and family boundaries]. Det politiska äktenskapet: 400 års historia om familj och reproduktion / ed. by Bente ROSENBECK, Hanne SANDERS, Jens RYDSTRÖM, Marie LINDSTEDT CRONBERG, Gunlög FUR. Stockholm: Makadam, 2010, p. 215-241.

JUFFER Femmie, VAN IJZENDOORN Marinus H. Adoptees do not lack self-esteem: A metaanalysis of studies on self-esteem of transracial, international and domestic adoptees. Psychological Bulletin, 2007, 133, p. 1067-1083.

KEATING, Jenny. Struggle for Identity: Issues Underlying the Enactment of the 1926 Adoption of Children Act. University of Sussex Journal of Contemporary History, 2001, 3, p. 1-9.

KEATING, Jenny. A Child for Keeps: the History of Adoption in England, 1918-1945. Basingstoke: Palgrave Macmillan, 2009.

KERSHAW Roger, SACKS Janet. New Lives for Old: the Story of Britain's Child Migrants. Richmond: National Archives, 2008.

KERTZER David I., BARBAGLI Marzio (ed.). Family Life in the Twentieth Century. New Haven: Yale University Press, 2003.

KERTZER, David I. Family Systems in Europe. International Encyclopedia of the Social and Behavioral Sciences / ed. par Neil J. SMELSER, Paul B. BALTES. Amsterdam: Elsevier, 2001, p. 5357-5361.

LALLEMAND, Suzanne. La circulation des enfants en société traditionnelle, prêt, don, échange. Paris : L'Harmattan, 1993.

LASLETT Peter, OOSTERVEEN Karla, SMITH Richard M. (eds.). Bastardy and its Comparative History. London: Edward Arnold, 1980.

LAVALLÉE, Carmen. Pour une adoption sans rupture du lien de filiation d'origine dans les juridictions de civil law et de common law. Informations sociales, 2008, 146(2), p. 132-140.

LE BOUTEILLEC, Nathalie. Parenté et illégitimité : réformes du droit de la filiation et de la famille en Suède au début du XXe siècle. Annales de démographie historique, 2013, 125(1), p. 69-97.

LEINAWEAVER, Jessaca B. Adoption, Demography of. International Encyclopedia of the Social and Behavioral Sciences (Second Edition) / ed. by Neil J. SMELSER, Paul B. BALTES. Amsterdam : Elsevier, 2015, p. 136-141.

LERIDON Henri, CHARBIT Yves, COLLOMB Philippe, SARDON Jean-Paul, TOULEMON Laurent. La seconde révolution contraceptive. La régulation des naissances en France de 1950 à 1985. Paris : INED/PUF, 1987.

LETT, Didier. Droits et pratiques de l'adoption au Moyen Âge. Médiévales, 1998, 35, p. 5-8.

LETT Didier, ROBIN Isabelle, ROLLET Catherine. Faire l'histoire des enfants au début du $\mathrm{XXI}^{\mathrm{e}}$ siècle : de l'enfance aux enfants. Annales de démographie historique, 2015, 129(1), p. 231-276.

LINDBLAD Frank, WEITOFT G. R., HJERN Anders. ADHD in international adoptees: a national cohort study. European Child and Adolescent Psychiatry, 2010, 19(1), p. 37-44.

LINDGREN, Cecilia. En riktig familj. Adoption, föräldraskap och barnets bästa 1917-1975 [A Real Family. Adoption, parenthood and the child's best interest 1917-1975]. Stockholm: Carlssons, 2006. 
LINDGREN, Cecilia. What is "in the best interest of the child"? Notions of biological and social kinship in Swedish child adoption policy 1917-1970. Uppväxt, familjeformer och barns bästa / ed. by Ingrid SÖDERLIND. Stockholm : Institutet för framtidsstudier, 2002.

MA, Li. Life course transitions of international adoptees in Sweden. Fortheoming.

MADDISON, Angus. The World Economy. Historical Statistics. Paris : OECD, 2003

MARMIER-CHAMPENOIS, Marie-Pierre. L'adoption. Effectivité de la loi du 11 juillet 1966. Approche des résultats de l'institution. Paris : Ministère de la Justice, 1978.

MASSON Judith, NORBURY Daphne, CHATTERTON Sandie G. Mine, yours, or ours? A study of step-parent adoption. London: H.M.S.O., 1983.

MIGNOT, Jean-François. Full adoption in England and Wales and France: a comparative history of law and practice (1926-2015). Adoption \& Fostering, 2017, 41(2), p. 142-158.

MIGNOT, Jean-François. "Simple" Adoption in France. Revival of an Old Institution (18042007). Revue française de sociologie, 2015a, 56(3), p. 365-394.

MIGNOT, Jean-François. Adoption in France and Italy: A Comparative History of Law and Practice (Nineteenth to Twenty-First Centuries). Population, 2015b, 70(4), p. 805-830.

MIGNOT, Jean-François. Why is intercountry adoption declining worldwide? Population and societies, $2015 \mathrm{c}, \quad 519, \quad$ p. $\quad 1-4 . \quad$ Available at $<$ http ://www.ined.fr/fichier/s_rubrique/23160/population.and.societies.2015.519.adoption.world.en.pd f>

MINISTÈRE DES AFFAIRES ÉTRANGÈRES. Statistiques de l'adoption internationale de l'Agence française de 1'adoption. 2016. Available at <http://www.agence-adoption.fr/le-paysage-deladoption-internationale/les-statistiques/>

MORIGUCHI, Chiaki. The Evolution of Child Adoption in the United States, 1950-2010. An Economic Analysis of Historical Trends. Economic Review, 2012, 63(3), p. 265-285.

MORIGUCHI, Chiaki. Child Adoption in Japan, 1948-2008. A Comparative Historical Analysis. Economic Review, 2010, 61(4), p. 342-357.

MOUTON, Michelle. Rescuing Children and Policing Families: Adoption Policy in Weimar and Nazi Germany. Central European History, 2005, 38(4), p. 545-571.

NEIRINCK, Claire. L'évolution de l'adoption. Parents de sang, parents adoptifs. Approches juridiques et anthropologiques de l'adoption. France, Europe, USA, Canada / ed. by Agnès FINE and Claire NEIRINCK, Paris: LGDJ, 2000, p. 343-361.

NEUKIRCHEN, Christoph. Die rechthistorische Entwicklung der Adoption. Frankfurt: Peter Lang, 2005.

O'DONOVAN, Katherine. L'adoption dans le droit du Royaume-Uni. Revue internationale de droit comparé, 2003, 55(4), p. 845-860.

O'HALLORAN, Kerry. The Politics of Adoption. International Perspectives on Law, Policy and Practice. New York: Springer, 2015.

OBSERVATOIRE NATIONAL DE L'ENFANCE EN DANGER. La situation des pupilles de l'État au 31 décembre. Paris, 2007-2016. Available at <http://oned.gouv.fr/mots-cles/pupille-letat>

OFFICE FOR NATIONAL STATISTICS. Annual Mid-year Population Estimates, 2014. 2015.

Available

<http://webarchive.nationalarchives.gov.uk/20160105160709/http://www.ons.gov.uk/ons/dcp171778_ 406922.pdf >

OFFICE FOR NATIONAL STATISTICS. Adoptions in England and Wales, 2012. 2013. http://webarchive.nationalarchives.gov.uk/20160105160709/http://www.ons.gov.uk/ons/dcp171778_3 22848.pdf>

ORGANISATION FOR ECONOMIC COOPERATION AND DEVELOPMENT. OECD Family Database / The Structure of Families / Fertility Indicators / Childlessness. 2016. Available at <http://www.oecd.org/els/family/SF_2-5-Childlessness.xlsx>

PALACIOS Jesús, BRODZINSKY David. Adoption research: Trends, topics, outcomes. International Journal of Behavioral Development, 2010, 34(3), p. 270284.

REHER, David Sven. Family Ties in Western Europe: Persistent Contrasts. Population and Development Review, 1998, 24(2), p. 203-234.

RIEG, Alfred. Adoption - Introduction comparative. Revue internationale de droit comparé, $1985,37(3)$, p. 511-524. 
RIVIÈRE, Antoine. Mères sans mari. Filles-mères et abandons d'enfants (Paris, 1870-1920). Genre \& Histoire, 2015, 16. Available at <http://genrehistoire.revues.org/2292>

ROSNATI Rosa, FERRARI Laura. Parental cultural socialization and perception of discrimination as antecedents for transracial adoptees' ethnic identity. Procedia - Social and Behavioral Sciences, 2014, 140(8), p. 103-108.

ROSSI Maria Clara, GARBELLOTTI Marina, PELLEGRINI Michele. Figli d'elezione. Adozione e affidamento dall'età antica all'età moderna. Florence: Carocci, 2014.

ROSSINI, Gill. A History of Adoption in England and Wales, 1850-1961. Barnsley: Pen \& Sword, 2014.

ROWLAND, Donald T. Historical Trends in Childlessness. Journal of Family Issues, 2007, 28(10), p. 1311-1337.

SCHULTZ, T. Paul. Fertility Transition: Economic Explanations. International Encyclopedia of the Social and Behavioral Sciences (Second Edition) / ed. par Neil J. SMELSER, Paul B. BALTES. Amsterdam: Elsevier, 2015, p. 60-67.

SELMAN, Peter. Global Statistics for Intercountry Adoption: Receiving States and States of origin, 2003-2013. 2015. Available at <https://assets.hcch.net/docs/3bead31e-6234-44ae-9f4e2352b190ca21.pdf>

SELMAN, Peter. Global Trends in Intercountry Adoption: 2001-2010. Adoption Advocate, 2012, 44, p. 1-17.

SELMAN, Peter. The rise and fall of intercountry adoption in the $21^{\text {st }}$ century. International Social Work, 2010, 52(5), p. 575-594.

SELMAN, Peter. Towards a Demography of Adoption: making sense of official statistics on child adoption and the search for origins. Paper presented at second international conference on adoption research, university of East Anglia, Norwich. 2006a.

SELMAN, Peter. Trends in Intercountry Adoption: Analysis of Data from 20 Receiving Countries, 1998-2004. Journal of Population Research, 2006b, 23(2), p. 183-204.

SOCIALSTYRELSEN. Adoption. Handbook for the Swedish Social Services. Vasteråas: Socialstyrelsen, 2009.

STATISTISCHES BUNDESAMT. Adoptierte Kinder und Jugendliche 1991-2011. Statistik der Kinder und Jugendhilfe. 2015.2 Available at <https://www.destatis.de/DE/Publikationen/Thematisch/Soziales/KinderJugendhilfe/Adoptionen52252 01137004.pdf?_blob=publicationFile>

STATISTISCHES BUNDESAMT. Öffentliche Sozialleistungen. Reihe 2. Wiesbaden: Öffentliche Jugendhilfe, 1977.

STATISTISKA CENTRALBYRÅN. Adopted children and young persons aged 0-21 by sex, age and country of birth. Year 2000-2014. 2016. Available at <http://www.scb.se/en_/Findingstatistics/Statistics-by-subject-area/Living-conditions/Living-conditions/Children-and-their-

Families/\#c_li_LE0102I>

STATISTISKA CENTRALBYRÅN. Historical Statistics of Sweden. Part 1. Population. 17201967. Stockholm: AB Allmänna Förlaget, 1969.

STEARNS, Peter N. History of Childhood. IACAPAP Textbook of Child and Adolescent Mental Health / ed. by Joseph M. REY. Geneva: International Association for Child and Adolescent Psychiatry and Allied Professions, 2015, p. 1-32. Available at <http://iacapap.org/wpcontent/uploads/J.9-HISTORY-OF-CHILDHOOD-2015.pdf>

STEARNS, Peter N. (ed.). Encyclopedia of European Social History from 1350 to 2000. Detroit: Scribner, 2001.

STUCHTEY, Benedikt. Solidarity with Children? Towards a History of Adoption. German Historical Institute London Bulletin, 2013, p. 43-56.

TANTURRI Maria Letizia, MILLS Melinda, ROTKIRCH Anna, SOBOTKA Tomáš, TAKÁCS Judit, MIETTINEN Anneli, FALUDI Cristina, KANTSA Venetia, NASIRI Despina. State-of-the-art report. Childlessness in Europe. Families and Societies Working Paper Series, 2015, 32, p. 1-53.

THERBORN, Göran. Between Sex and Power. Family in the world, 1900-2000. New York: Routledge, 2004. 
THOMSON, Elizabeth. Children, Value of. International Encyclopedia of the Social and Behavioral Sciences (Second Edition) / ed. par Neil J. SMELSER, Paul B. BALTES. Amsterdam: Elsevier, 2015, p. 498-501.

TILLY Louise A., FUCHS Rachel G., KERTZER David I., RANSEL David L. Child Abandonment in European History: A Symposium. Journal of Family History, 1992, 17(1), p. 1-23.

UNITED NATIONS. Child Adoption: Trends and Policies. New York: United Nations Publications, 2009.

UNITED NATIONS POPULATION DIVISION. World Population Prospects: The 2015 Revision, 2015. Available at <http://esa.un.org/wpp/>. a

UNITED NATIONS POPULATION DIVISION. World Urbanization Prospects: The 2014 Revision, 2015. Available at <https://esa.un.org/unpd/wup/CDROM/WUP2014_XLS_CD_FILES/WUP2014-F02-Proportion_Urban.xls>.b

VALLIN, Jacques. Europe's Demographic Transition, 1740-1940. Demography. Analysis and synthesis. A Treatise in Population. Volume III / ed. by Graziella CASELLI, Jacques VALLIN, Guillaume WUNSCH. Paris: Academic Press, 2005, p. 41-66.

VERDIER, Pierre. L'enfant en miettes. Toulouse : Édouard Privat, 1986.

VOLK, Anthony A. Adoption: Forms, Functions and Preferences. The Oxford Handbook of Evolutionary Family Psychology / ed. by Catherine SALMON, Todd K. SHACKELFORD. Oxford: Oxford University Press, 2011, p. 113-127.

WALKER, Pamela J. Adoption and Victorian Culture. History of the Family, 2006, 11, p. 211 221.

WEIL, Richard H. International Adoptions: The Quiet Migration. International Migration Review, 1984, 18, p. 276-293. 